NBER WORKING PAPER SERIES

\title{
REPATRIATION TAXES, REPATRIATION STRATEGIES AND MULTINATIONAL FINANCIAL POLICY
}

\author{
Rosanne Altshuler \\ Harry Grubert
}

Working Paper 8144

http://www.nber.org/papers/w8144

\author{
NATIONAL BUREAU OF ECONOMIC RESEARCH \\ 1050 Massachusetts Avenue \\ Cambridge, MA 02138 \\ March 2001
}

This paper was prepared for presentation at the NBER Trans-Atlantic Public Economics Seminar, Gerzensee, Switzerland, May, 2000. We are grateful to two anonymous referees, Mihir Desai, Michael Devereux, Roger Gordon, and participants at the Trans-Atlantic Public Economics Seminar for helpful comments. We thank Gordon Wilson and Paul Dobbins for providing us with the data files in a convenient form. Any opinions expressed are those of the authors and not of the U.S Treasury Department. The views expressed herein are those of the authors and not necessarily those of the National Bureau of Economic Research.

(C) 2001 by Rosanne Altshuler and Harry Grubert. All rights reserved. Short sections of text, not to exceed two paragraphs, may be quoted without explicit permission provided that full credit, including $\odot$ notice, is given to the source. 
Repatriation Taxes, Repatriation Strategies and Multinational Financial Policy

Rosanne Altshuler and Harry Grubert

NBER Working Paper No. 8144

March 2001

JEL No. H25, H87

\begin{abstract}
$\underline{\text { ABSTRACT }}$
Several investment-repatriation strategies are added to the standard model of a multinational in which an affiliate is located in a low-tax country and is limited to two alternatives: repatriating taxable dividends to the parent or investing in its own real operations. In our model, affiliates can invest in passive assets, which the parent can borrow against, or in related affiliates which can be used as vehicles for tax-favored repatriations. We show analytically how the availability of alternative strategies can effect real investment throughout the worldwide corporation. We use firm level data for U.S. multinationals to test for the importance of alternative strategies. The evidence is generally consistent with the theory, particularly the strategies using related affiliates.
\end{abstract}

Rosanne Altshuler Department of Economics

Rutgers University

75 Hamilton Street

New Brunswick, NJ 08901-1248

altshule@rci.rutgers.edu
Harry Grubert

U.S. Department of Treasury Office of Tax Analysis International Taxation 1500 Pennsylvania Avenue, N.W. Washington, D.C. 20220

Harry.Grubert@do.treas.gov 
In spite of the widespread interest in globalization, the literature on the behavior of multinational corporations (MNCs) tends to focus on a limited range of financial flows between foreign affiliates and parents. ${ }^{1}$ In the standard model, the MNC is subject to a credit and deferral tax system at home and typically operates one affiliate in a low-tax country. After capitalizing the affiliate the MNC chooses between direct dividend remittances to the parent and further real investment in the foreign affiliate. Paying dividends is a costly alternative from a tax perspective since these remittances are subject to the higher home country tax rate when received by the parent. However, real investment in the foreign affiliate, which may generate inferior returns relative to investment at home, is only one of many alternatives to direct dividend repatriations. The MNC can engage in a variety of other strategies that have the effect of achieving the equivalent of repatriation without incurring the home country tax on direct repatriations of low-tax income.

One alternative to direct repatriation and investment in its real operations is investment in passive assets such as Eurodollar deposits. Depending on the size of the interest yield compared to the MNC's equity return, this may be as good as direct remittances. Beyond that, even if after-tax interest rates are low compared to equity returns, the MNC can achieve the complete equivalent of a tax-free direct repatriation if the parent can borrow against the passive assets held by the subsidiary. Once borrowing is an option, direct flows between affiliate and parent are no longer necessary --- the earnings in the low-tax country can support investment at home without bearing the burden of the U.S. corporate tax.

Instead of investing in passive assets or reinvestment, the low-tax affiliate with potentially high taxes on direct repatriations can invest in, or lend to, a related foreign affiliate. This keeps the funds within the worldwide corporation and generates a triangular flow of funds within the MNC. Further, as long as the related downstream affiliate is not located in a low-tax country, it can become the vehicle for tax-free repatriation by the low-tax subsidiary. To achieve this result, the low-tax subsidiary invests in the related affiliate which then repatriates all of its income to the parent. Equity injections from the low-

\footnotetext{
${ }^{1}$ See the theoretical models in Sinn (1984) and Hartman (1985). The empirical work by Hines and Hubbard (1990), and Altshuler, Newlon and Randolph (1995), also focus primarily on dividend repatriations.
} 
tax subsidiary are then used to fund the operations of the related affiliate. As will be explained further below, under credit and deferral tax systems remittances from countries with tax rates greater or equal to home country rates generate no residual home country taxes. This "triangular" strategy therefore allows the parent to effectively convert the income earned in the low-tax subsidiary into high-tax income which can be costlessly repatriated.

Another "triangular" strategy that links the operations of related affiliates is one in which the lowtax affiliate is initially capitalized by an equity injection from an upper-tier subsidiary facing a higher host country tax rate. Then any dividend from the low-tax affiliate up the tier obtains a "blended" higher tax rate for the purpose of tax credits against the home country tax when the dividend reaches the parent.

The first part of the paper adds these alternative strategies to a model of a MNC and its worldwide operations. The analysis shows how broadening the strategies available to the MNC can affect real investment in the worldwide corporation. If the low-tax affiliate can achieve the equivalent of taxfree repatriations, it does not have to initially "underinvest," as in Sinn (1993), to obtain the benefits of deferral. The repatriation tax is not capitalized into the cost of capital in the low-tax subsidiary, it is effectively avoided. Furthermore, the strategies considered can affect the cost of capital elsewhere in the MNC. If it is useful to have a high-tax affiliate as a vehicle for low or zero taxes on repatriations, this may increase the value of high-tax investment. Similarly, if investment by the parent at home can enhance its ability to put more tax-deductible borrowing on its own books, investment at home can become more advantageous.

The paper then goes on to explore the empirical importance of the strategies developed in the analytical section using the 1996 U.S. Treasury data file for MNC parents and their controlled foreign

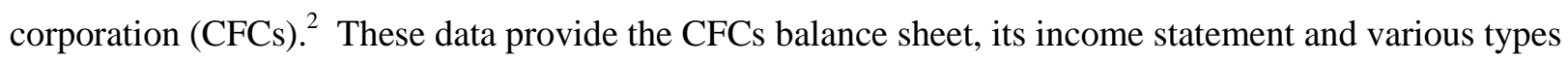
of transactions with related parties.

\footnotetext{
${ }^{2} \mathrm{~A}$ CFC is a foreign corporation that is at least 50 percent owned by a group of U.S. shareholders each of whom have at least a 10 percent interest in the company.
} 
The regressions generally provide strong support for the strategies presented in the model. CFCs that face a potentially high-tax on direct repatriations invest a greater amount in related affiliates and extend more loans to them. The empirical analysis also strongly supports the "blending" strategy of sending low-tax income through tiers. CFCs with high repatriation taxes distribute a significantly greater share of their dividends to their foreign affiliates rather than directly to the United States. The results on passive assets are less robust, which may not be surprising in view of the possible inferiority of this strategy outlined in the analytic section. Further, examining the growth of CFC real capital from the date of their incorporation fails to reveal any pattern of underinvestment motivated by repatriation taxes.

Finally, the data on CFC liabilities show that CFCs in high-tax rate countries have much more debt on their books. Furthermore, as CFCs with high potential repatriation taxes accumulate retained earnings, they pay off more local debt, which is another, less costly, version of the passive assets strategy. The retained earnings are not invested exclusively in operating, real assets.

Recent findings on repatriation rates by low-tax CFCs confirm our view that companies can largely escape the burden of potentially high taxes on repatriations. Grubert and Mutti (1999) find that manufacturing subsidiaries in countries with effective tax rates below ten percent only repatriate an average of seven percent of their earnings. Even "mature" CFCs are found to have modest repatriation rates --- the ratio of dividends to current earnings and profits for CFCs incorporated more than fifteen years ago was less than twenty percent. This paper outlines strategies that firms can use to achieve this result.

The paper is organized as follows: Section 1 provides a brief explanation of U.S. tax policy towards real and financial investments abroad. Section 2 presents a simple model that can be used to explore the impact of taxes on the investment policies of foreign affiliates. We start by imposing the standard arbitrage condition used by Sinn (1993) and others which requires that the after-tax interest rate (using the home-country tax rate) is equal to the return on equity. We then consider how repatriation and investment policies change when we drop this arbitrage condition and impose a worldwide debt-to-asset constraint. Under the latter constraint, borrowing against passive assets becomes a viable strategy. We 
also study how debt and real capital should be allocated across parent and affiliate operations under our worldwide financial constraint. Section 3 contains our empirical results and section 4 briefly summarizes our results and concludes.

\section{U.S. Tax Treatment Of Returns To Real And Financial Investments Abroad}

We start by explaining how the U.S. tax code treats the returns to real and financial investments of U.S. multinational corporations. The active business profits of CFCs are generally not subject to U.S. taxation until they are remitted to U.S. parent corporations. As explained below, when repatriations do occur they receive a credit for foreign taxes paid up to the U.S. tax rate. However, this limitation on the credit is on a "basket" or type of income basis. A consequence is that foreign tax credits generated from one type of income (highly taxed dividends, for example) can not be used to offset the U.S. tax liability generated from another type of income (lightly taxed portfolio income, for example).

The deferral of U.S. tax until repatriation has repeatedly been attacked for encouraging U.S. firms to avoid U.S. taxes on foreign income by retaining it abroad in low-tax jurisdictions. Provisions that limit the deferral of foreign profits were added to the tax code in 1962 and have been progressively tightened through subsequent tax reforms. In general, these "anti-tax avoidance" provisions (contained in Subpart F

of the Internal Revenue Code) limit deferral to earnings from active business investments abroad. Earnings from financial assets are denied deferral and taxed immediately.

The current taxation of financial income has different consequences for purely passive assets and for investments in equity or debt of other affiliates. Under the "look through" rule for CFCs, income from loans or equity in affiliates in other countries can be in the parent's general (active) income basket if the affiliate is engaged in active operations. This lightly taxed income can then be mixed in with highly taxed dividends for the purpose of the foreign tax credit. Mixing, or "averaging", income subject to high and low tax rates abroad results in lower U.S. tax liabilities on foreign income than would result if the credit were calculated separately for each type of income. In contrast, truly passive income such as Eurodollar 
interest would be in the parent's passive basket (which will consist mainly of lightly taxed income) and would in all likelihood be subject to full U.S. tax.

Loans and equity in affiliates also have different tax consequences since they differ in the extent to which income has to be currently accrued. While interest has to be paid annually, equity income can be deferred through the non-payment of dividends. Further, when dividends are paid to parents partly out of dividends received from upper-tier affiliates, the repatriation tax due to the U.S. Treasury on the dividend is a "blend" of the tax rates in the high and low tax affiliates. If high-tax affiliates capitalize low-tax affiliates, repatriations of earnings in the low-tax affiliate can be effectively funneled to the parent at a lower repatriation tax cost than if they were paid directly to the parent from the low-tax affiliate. This "multiple tiers" strategy is discussed further in section 2.1.

Even though they can have differing tax consequences, which will play an important role in our empirical work, passive assets and investments in (or loans to) affiliates are similar in that they offer the CFC alternatives in addition to repatriation to the parent. Both can be used to avoid income from being "trapped" in the CFC's real assets. Furthermore, as we will see, even though passive investments have tax disadvantages and may yield a low real return compared to "in house" investments, the value of the passive assets can be comparable to investment inside the multinational if the assets can be used to support borrowing by the parent.

\section{The Theoretical Implications of Investment in Financial Assets}

We start with the simple two-period model presented in Grubert (1998) in which reinvestment in real assets held in subsidiaries abroad is the only alternative to dividend repatriations. ${ }^{-1}$ At the end of period zero, a foreign affiliate located in country $\mathrm{j}$ receives an initial equity injection, $\mathrm{K}_{\mathrm{j}, 0}$, from the

\footnotetext{
${ }^{3}$ These types of provisions also appear in the tax codes of Germany, Canada, and the U.K., for example.

${ }^{4}$ The repatriation strategies presented later in this section are extremely difficult to model in an infinite horizon setting. As we show below, the two-period model captures the impact of our alternative repatriation strategies and worldwide financial constraint on the MNC's investment and financial policy in a transparent way. There is at least one drawback to using a two-period model in which production functions are stationary over time, however. Our model is too simple to capture the benefits of the "multiple tiers" strategy which, as explained below, depends on the
} 
parent. In each subsequent period, the affiliate produces using a standard production function $\mathrm{f}_{\mathrm{j}}(\mathrm{K})$ with $\mathrm{f}_{\mathrm{j}}{ }^{\prime}>0$ and $\mathrm{f}_{\mathrm{j}}^{\prime \prime}<0$. For simplicity, we assume that real capital, $\mathrm{K}$, does not depreciate and impose the standard arbitrage condition that $r=i(1-t)$ where $r$ is the required rate of return on equity at home aftercorporate-tax, $t$ represents the statutory U.S. corporate tax rate, and $\mathrm{i}$ is the rate of return on the world capital market. In period 1 , the foreign affiliate earns an after-foreign-tax return of $f_{j}\left(K_{j, 0}\right)\left(1-t_{j}\right)$, where $t_{j}$ is the statutory corporate tax rate in the host country. At the end of period 1 , the parent may retain $\left(\mathrm{R}_{\mathrm{j}}\right)$ for reinvestment in the production process or pay dividends $\left(\mathrm{D}_{\mathrm{j}}\right)$. The parent may also inject additional equity, $\mathrm{E}_{\mathrm{j}}$, into the affiliate in period 1 . Let $\mathrm{K}_{\mathrm{j}, 1}$ equal the total equity transfers held in the affiliate in the beginning of period 2 so that $\mathrm{K}_{\mathrm{j}, 1}=\mathrm{K}_{\mathrm{j}, 0}+\mathrm{E}_{\mathrm{j}}$. In period 2, the affiliate generates after-foreign-tax earnings of $f_{j}\left(K_{j, 1}+R_{j}\right)\left(1-t_{j}\right)$. At the end of period 2, the entire net worth of the affiliate is repatriated: $f_{j}\left(K_{j, 1}+R_{j}\right)(1-$ $\left.t_{j}\right)+K_{j, 1}+R_{j}$.

As long as there are any accumulated earnings or profits within the affiliate, any distributions (including equity repatriations) from the affiliate to the parent are subject to U.S. taxation. Let $\mathrm{t}_{\mathrm{j}, \mathrm{d}}$ represent the repatriation tax on remittances from the foreign affiliate in country $\mathrm{j}$. Then, cash-flows between parent and affiliate in our simple model, after host and home country taxes, can be described as follows in chart 1.

Chart 1

After-tax cash-flows when the only alternative to dividends is reinvestment in real assets

\begin{tabular}{|l|l|l|l|}
\hline & End of period 0 & End of period 1 & End of period 2 \\
\hline $\begin{array}{l}\text { From parent: } \\
\text { To affiliate in country } \mathrm{j}\end{array}$ & $\mathrm{K}_{\mathrm{j}, 0}$ & $\mathrm{~K}_{\mathrm{j}, 1}-\mathrm{K}_{\mathrm{j}, 0}$ & \\
\hline $\begin{array}{l}\text { To parent: } \\
\text { From affiliate in country } \mathrm{j}\end{array}$ & & $\mathrm{D}_{\mathrm{j}}\left(1-\mathrm{t}_{\mathrm{j}, \mathrm{d}}\right)$ & $\mathrm{f}_{\mathrm{j}}\left(\mathrm{K}_{\mathrm{j}, 1}+\mathrm{R}_{\mathrm{j}}\right)\left(1-\mathrm{t}_{\mathrm{j}}\right)\left(1-\mathrm{t}_{\mathrm{j}, \mathrm{d}}\right)+\mathrm{K}_{\mathrm{j}, 1}+\mathrm{R}_{\mathrm{j}}\left(1-\mathrm{t}_{\mathrm{j}, \mathrm{d}}\right)$ \\
\hline
\end{tabular}

At this point it is necessary to explain how the repatriation tax is determined. Consider the taxes paid abroad on a dividend payment of $D_{j}: t_{j} D_{j} /\left(1-t_{j}\right)+\omega_{j} D_{j}$ where $\omega_{j}$ denotes the host country withholding

presence of growing investment opportunities abroad. The models in Sinn (1993) and Weichenrieder (1996), whose results we extend later in this section, also impose stationary production functions. 
tax rate on dividends. ${ }^{\mathrm{E}}$ The U.S. tax liability on the grossed up dividend payment is $\mathrm{tD}_{\mathrm{j}} /\left(1-\mathrm{t}_{\mathrm{j}}\right)$. Allowing a foreign tax credit for the taxes paid abroad reduces this home tax liability to $\left(t-t_{j}\right) D_{j} /\left(1-t_{j}\right)-\omega_{j} D_{j}$. The foreign tax credit is limited, however, to the U.S. tax liability on foreign source income 6 If foreign taxes exceed the limitation then there is no residual U.S. tax on the dividend remittance. Since the parent does not receive a full credit for taxes paid abroad it is said to be in "excess credit." In this case, the tax cost of dividend repatriations to the parent (including U.S. and source country taxes) is $t_{j, d}=\omega_{j}$. If, on the other hand, foreign taxes are less than the foreign tax credit limit, the parent receives a full credit for taxes paid to the host country and is said to be in "deficit credit" or "excess limitation." In this case, the tax cost of dividend repatriations is $t_{j, d}=\left(t-t_{j}\right) /\left(1-t_{j}\right)$. We call this repatriation tax the "deficit credit tax price" in our empirical work. Note that when the parent is in a deficit credit position, a dollar of foreign earnings in the hands of the parent after host country taxes $\left(t_{j}\right)$ and repatriation taxes $\left(t_{j, d}\right)$ equals $\$(1-t)$.

Optimal repatriation strategies, financial policy, and investment decisions depend on whether the parent has excess foreign tax credits. It is therefore necessary to examine optimal policies separately for

\footnotetext{
${ }^{5}$ For the purpose of the foreign tax credit, the dividend is "grossed up" by the foreign effective tax rate which may differ from the statutory rate if, for example, the foreign government provides investment incentives such as accelerated depreciation and investment credits. Although we make a distinction between effective and statutory tax rates in our empirical work, we assume (for simplicity) in our theoretical work that effective and statutory tax rates are equal. Papers by Leechor and Mintz (1993) and Hines (1994) show how investment incentives are affected in situations in which foreign effective tax rates differ from statutory tax rates. Using statutory rates to represent the dividend gross-up rate does not affect our qualitative results.

${ }^{6}$ If the parent owns only one subsidiary abroad its foreign tax credit position depends only on host country taxes in the subsidiary. However, if the parent has more than one affiliate, or if it receives different types of income from operations abroad (such as royalty or interest income), its foreign tax credit position in any "basket" of income will depend on its average tax rate of foreign source income. The parent is in a deficit credit position if its average tax rate on foreign source income is less than the U.S. rate and in an excess credit position otherwise. The limitation on the foreign tax credit operates to some extent on an overall basis. This means that credits accruing from one source of foreign income can often be used to offset U.S. tax on foreign income from another source. As noted in section 1, cross-crediting is only possible if the income is in the same foreign tax credit basket.

${ }^{7}$ Under current law, excess credits can be carried back to offset any U.S. tax payments on foreign-source income made in the previous two years. Credits may also be carried forward without interest and used to offset U.S. tax liability in the following five years. Note that the tax cost that we use in our theoretical and empirical work is a "current" remittance cost that does not include an adjustment for foreign tax credit carrybacks or carryforwards. We abstract from the possibility that investment and financial policies may cause parents to switch credit positions to focus on the impact of alternatives to repatriation on economic decisions.
} 
parents in excess and deficit credit positions. We focus on the (stationary) deficit credit case in the next section and the (stationary) excess credit case in section 2.2.

\subsection{Incentives for parents in deficit credit positions}

Consider a parent investing in an affiliate located in country $\mathrm{j}$. The parent's problem is to choose $\mathrm{K}_{\mathrm{j}, 0}, \mathrm{~K}_{\mathrm{j}, 1}$, and $\mathrm{R}_{\mathrm{j}}$ to maximize the present value of net cash-flows to the parent subject to the usual cashflow constraint:

$$
\begin{gathered}
\max -K_{j, 0}+(1+r)^{-1}\left[D_{j}\left(1-t_{j, d}\right)-\left(K_{j, 1}-K_{j, 0}\right)\right]+(1+r)^{-2}\left[f_{j}\left(K_{j, 1}+R_{j}\right)(1-t)+K_{j, 1}+R_{j}\left(1-t_{j, d}\right)\right] \\
\text { subject to } D_{j}=f_{j}\left(K_{j, 0}\right)\left(1-t_{j}\right)-R_{j}
\end{gathered}
$$

Before solving this problem, we compare the impact of equity injections and retentions on the maximand. A dollar of retentions at the expense of a positive equity injection increases the after-tax value of equity by $\mathrm{rt}_{\mathrm{j}, \mathrm{d}}$. Thus, retentions dominate additional equity injections if repatriation taxes are positive (when $\mathrm{t}_{\mathrm{j}}<\mathrm{t}$ ).

We start by considering the standard case in which the affiliate is located in a country with a low statutory corporate tax rate relative to the U.S.: $t_{j}=t_{L}<t$. The first-order conditions give the following rules for investment:

$$
\begin{array}{ll}
f_{L}^{\prime}\left(K_{L, 1}+R_{L}\right)\left(1-t_{L}\right)=r & \text { with respect to } R \\
f_{L}^{\prime}\left(K_{L, 0}\right)(1-t)=1+r-\frac{1+r\left(1-t_{L, d}\right)}{1+r} & \text { with respect to } K_{L, 0}
\end{array}
$$

The first condition is the standard Hartman-Sinn result: the capital stock in the second period is a function of the foreign tax rate and not the repatriation tax $t_{L, d}$. The second condition indicates that repatriation taxes do play a role in determining the optimal equity injection. The parent injects less capital in the affiliate than it would under an exemption or territorial tax system since it can obtain the

\footnotetext{
${ }^{8}$ Weichenrieder (forthcoming) analyzes a case in which the overall tax on repatriating income is higher than the home country tax rate. This could occur if the parent has excess credits. As he shows, the MNC has an incentive to shift income back to the parent to avoid the tax on repatriating income. In the deficit credit case, income shifting back to the parent would not offer an advantage because any saving in foreign tax is just offset by lower tax credits. However, income shifting to low-tax countries is complementary with the strategies we describe since sending funds home from low-tax countries becomes more important in this case.
} 
benefits of deferral until it reaches the "target" capital stock. The initial equity injection increases as the repatriation tax and, consequently, the benefits of deferral decrease.

For an affiliate located in a country with a relatively high corporate statutory rate $\left(t_{j}=t_{H}>t\right)$ there is no advantage to deferral. ${ }^{\text {G }}$ High-tax subsidiaries are immediately capitalized to their steady-states.

Optimal retentions are zero (since the repatriation tax, $\mathrm{t}_{\mathrm{H}, \mathrm{d}}$, is negative), all earnings are distributed at the end of each period, and the first-order condition with respect to both $\mathrm{K}_{\mathrm{H}, 0}$ and $\mathrm{K}_{\mathrm{H}, 1}$ is:

$$
\mathrm{f}_{\mathrm{H}}^{\prime}(\bullet)(1-\mathrm{t})=\mathrm{r}
$$

Since the parent is in deficit credits it faces the U.S. tax rate on investment in affiliates in high-tax countries.

\section{Investing in Passive Assets as an Alternative to Repatriation}

Now that we have reproduced the standard Hartman-Sinn results, we study the implications of allowing parents to reinvest active earnings in the world capital market. Weichenrieder (1996) extends the Hartman-Sinn model to consider how the size and growth of foreign affiliates is affected by "anti-tax avoidance" rules that limit deferral to earnings on active investments abroad. We present a simple version of his result here to compare with the results we obtain when we allow for additional alternatives to repatriation and drop the standard arbitrage condition.

In our new model, at the end of period 1, the parent decides between reinvestment in real capital, dividends, and investment in passive assets $\left(\mathrm{P}_{\mathrm{j}}\right)$ which earn an after-foreign-tax return of $\mathrm{i}\left(1-\mathrm{t}_{\mathrm{j}}\right)$. Although earnings from passive assets held in subsidiary $\mathrm{j}$ are taxed as if they were remitted as dividends, the reinvested foreign earnings are not taxed until repatriated. Chart 2 shows cash-flows between the parent and its affiliates (differences between cash-flows in charts 1 and 2 are highlighted.)

\footnotetext{
${ }^{9}$ We assume that the presence of low-tax remittances such as royalties, for example, from elsewhere in the MNC keeps the parent in a deficit credit position regardless of remittances from the high-tax affiliate.
} 


\begin{tabular}{|c|c|c|c|}
\hline \multicolumn{4}{|c|}{$\begin{array}{c}\text { Chart } 2 \\
\text { After-tax cash-flows when alternatives to dividends are reinvestment in real assets or } \\
\text { investment in passive assets }\end{array}$} \\
\hline & $\begin{array}{l}\text { End of } \\
\text { period } 0\end{array}$ & $\begin{array}{l}\text { End of } \\
\text { period } 1\end{array}$ & End of period 2 \\
\hline $\begin{array}{l}\text { From parent to: } \\
\text { affiliate in country } j\end{array}$ & $\mathrm{~K}_{\mathrm{j}, 0}$ & $\mathrm{~K}_{\mathrm{j}, 1}-\mathrm{K}_{\mathrm{j}, 0}$ & \\
\hline $\begin{array}{l}\text { To parent from: } \\
\text { affiliate in country } j\end{array}$ & & $\mathrm{D}_{\mathrm{j}}\left(1-\mathrm{t}_{\mathrm{j}, \mathrm{d}}\right)$ & $f_{j}\left(K_{j, 1}+R_{j}\right)(1-t)+K_{j, 1}+R_{j}\left(1-t_{j, d}\right)+\mathbf{P}_{j}\left(1-t_{j, d}\right)+i P_{j}(1-t)$ \\
\hline
\end{tabular}

To simplify the analysis, before solving the problem we establish the conditions under which an affiliate should pay dividends at the expense of investment in passive assets. On one hand, an additional dollar of dividends generates $\left(1-\mathrm{t}_{\mathrm{j}, \mathrm{d}}\right) /(1+\mathrm{r})$ after taxes. On the other hand, the after-tax return of a dollar invested in passive assets at the expense of dividends is $\left(1-t_{j, d}+i(1-t)\right) /(1+r)^{2}$. As long as the net of tax interest rate earned abroad, $\mathrm{i}\left(1-\mathrm{t}_{\mathrm{j}}\right)$, exceeds the required rate of return on equity, $\mathrm{r}$, investment in passive assets dominates dividend payments. Since we have assumed that $r$ is equal to $i(1-t)$, only affiliates in low-tax countries should invest in passive assets. As a result, investment rules for affiliates in high-tax countries are not affected by the presence of passive investment opportunities.

Solving the parent's maximization problem for the optimal value of $\mathrm{K}_{\mathrm{L}, 0}, \mathrm{~K}_{\mathrm{L}, 1}, \mathrm{R}_{\mathrm{L}}$ and $\mathrm{P}_{\mathrm{L}}$ given that $D_{L}=0$ leaves us with three possible cases: (i) $R_{L}=0$ and $P_{L}>0$, (ii) $R_{L}>0$ and $P_{L}=0$, and (iii) $R_{L}>0$ and $\mathrm{P}_{\mathrm{L}}>0$. However, our standard assumptions on the production function ensure that only the first case may obtain for $\mathrm{t}_{\mathrm{L}}<\mathrm{t} .10$ Thus, maximizing the value of equity held in the affiliate requires that all returns from real investment at the end of period 1 be reinvested in passive assets. The first-order conditions for investment with respect to $\mathrm{K}_{\mathrm{L}, 0}$ and $\mathrm{K}_{\mathrm{L}, 1}$ are:

\footnotetext{
${ }^{10}$ Taking partial derivatives of the value function with respect to $R_{L}$ and $P_{L}$ shows that retentions dominate passive assets (case ii) only if $f_{L}^{\prime}\left(K_{L, 1}+R_{L}\right)>i$. Solving for optimal $K_{L, 0}$ and $R_{L}$ and imposing concavity of $f_{L}$ shows that $f^{\prime}$, $\left(\mathrm{K}_{\mathrm{L}, 1}+\mathrm{R}_{\mathrm{L}}\right)>\mathrm{i}$ only if $\mathrm{t}<\mathrm{t}_{\mathrm{L}}$. Thus, case (ii) can not exist when the affiliate is located in a low-tax country. Case (iii) requires that $f^{\prime}{ }_{L}\left(K_{L, 1}+R_{L}\right)=i$. However, when $R_{L}>0$ and $P_{L}>0$, $f_{L}^{\prime}\left(K_{L, 0}\right)<f_{L}^{\prime}\left(K_{L, 1}+R_{L}\right)=i$ when $t>t_{L}$. Convexity is violated and therefore this case can not exist for $t>t_{L}$.
} 


$$
\mathrm{f}_{\mathrm{L}}^{\prime}(\bullet)(1-\mathrm{t})=\mathrm{r}\left(\frac{2+\mathrm{r}}{2+\frac{\mathrm{r}}{1-\mathrm{t}_{\mathrm{L}, \mathrm{d}}}}\right)
$$

The parent immediately capitalizes its low-tax affiliates to the steady-state level of capital.

The investment rule indicates that in the presence of passive assets, there is no longer an incentive to "underinvest" in the foreign affiliate located in the low-tax country. 11 Unlike in the Hartman-Sinn model, equity is no longer "trapped" in this foreign affiliate since it may be used to invest in the world capital market. The affiliate obtains the benefits of deferral on active income by investing the income in passive assets. It is never optimal to reinvest any first period earnings in real foreign assets because the CFC can always earn $\mathrm{i}\left(1-\mathrm{t}_{\mathrm{L}}\right)=\mathrm{r} /\left(1-\mathrm{t}_{\mathrm{L}, \mathrm{d}}\right)$ on passive assets. The affiliate pays no dividends, retains no earnings, and effectively transfers first period after-tax earnings, $f_{L}\left(K_{L, 0}\right)\left(1-t_{L}\right)$, to the parent at the end of period 1.

With a finite horizon and ultimate repatriation of all income, the cost of capital depends on the closure date of the firm since it determines the benefits of deferral. However, in an infinite horizon setting neither equity or principal would be repatriated. As a result, the 2's would be eliminated from both the numerator and denominator in equation (4) and the Hartman-Sinn result $\left[\mathrm{f}_{\mathrm{L}}^{\prime}(\bullet)=\mathrm{r} /\left(1-\mathrm{t}_{\mathrm{L}}\right)\right]$ would obtain. ${ }^{12}$ From the beginning, the parent invests in real assets in the low-tax affiliate as if foreign income were exempt from U.S. taxation because it can always earn a normal return on its passive retained assets. This result is derived using a infinite period dynamic optimization model in Weichenrieder (1996).

\section{Investing in a High-Tax Affiliate as an Alternative to Repatriation}

Even in a traditional all equity model the multinational can achieve the same results without investing in purely passive assets if it also has another CFC in a country with a tax rate at least equal to the U.S. (home country) rate. To see this, we now depart from the standard analysis and allow the parent

\footnotetext{
${ }^{11}$ Although Hines (1994) does not explicitly model the option of investing in passive assets, he also concludes that there is no incentive to underinvest if firms can freely borrow and lend at world interest rates.
} 
the option of investing profits earned abroad in other related affiliates. Specifically, we consider a parent that invests in a low-tax and a high-tax CFC simultaneously. 3 At the end of the first period, we allow the low-tax subsidiary to invest in the high-tax subsidiary and vice-versa. As explained further below, in a two-period model investment in the high-tax subsidiary using funds from the low-tax subsidiary (the "triangular" strategy) will dominate capitalizing the low-tax subsidiary using funds from the high-tax subsidiary (the "multiple tiers" strategy). Consequently, we start by considering investment rules for the "triangular" case.

Let $\mathrm{H}$ equal the investment in the high-tax subsidiary from earnings in the low-tax subsidiary and $\mathrm{s}$ equal the resulting share of equity owned by the low-tax affiliate, $\mathrm{s}=\mathrm{H} /\left(\mathrm{K}_{\mathrm{H}, 1}+\mathrm{R}_{\mathrm{H}}\right) .41$ Equity injections in the high-tax CFC now may consist of transfers from the parent at the end of periods 0 and 1 , as well as transfers from the low-tax CFC at the end of period 1. Thus, $\mathrm{K}_{\mathrm{H}, 1}=\mathrm{K}_{\mathrm{H}, 0}+\mathrm{E}_{\mathrm{H}}+\mathrm{H}$.

Before proceeding with the analysis, it is necessary to be precise about the U.S. taxation of the equity and profits held in the low-tax CFC at the end of the second period. It is taxed on all of its accumulated earnings and profits including its investment in the high-tax affiliate. However, when the low-tax subsidiary receives a dividend from the high-tax subsidiary at the end of period two, there will be no tax owing in the low-tax country because dividends are either exempt from taxation (if the low-tax country runs a territorial system) or shielded by credits (if instead the low-tax country uses a worldwide system). When the income is finally repatriated by the low-tax subsidiary to the U.S. (at the end of period 2 in our model), the dividend will carry the lower tier taxes paid (in the high-tax subsidiary) as a credit. 15 As will become clear below, this makes the triangular case entirely equivalent to the passive assets case in the previous section.

\footnotetext{
${ }^{12}$ As the time horizon increases, the present value of the unrepatriated capital goes to zero.

${ }^{13}$ Using a similar dataset to ours for 1986, Altshuler and Newlon (1993) find that almost three-quarters of the parents had CFCs in both high- and low-tax countries.

${ }^{14}$ Note that in our simple two-period model, the parent will be indifferent between transmitting capital from the lowtax CFC to the high-tax CFC in the form of a loan or an investment.

${ }^{15}$ Under current U.S. tax law, taxes paid up through six tiers of affiliates can be credited against U.S. taxes on foreign source income through the foreign tax credit mechanism.
} 
Chart 3 shows interaffiliate transactions along with the cash-flows between the parent and its affiliates for the "triangular strategy." (Differences between cash-flows in charts 1 and 3 are highlighted.) The return on $H$ paid to the low-tax affiliate at the end of period 2 is $\operatorname{sf}_{H}\left(K_{H, 1}+R_{H}\right)\left(1-t_{H}\right)$. As explained above, taxes paid abroad on this dividend remittance are offset by foreign tax credits of $t_{H} * f_{H}\left(K_{H, 1}+R_{H}\right)$ when the dividend is finally repatriated to the parent.

\begin{tabular}{|c|c|c|c|}
\hline \multicolumn{4}{|c|}{$\begin{array}{l}\text { Chart } 3 \\
\begin{array}{c}\text { After-tax cash-flows when alternatives to dividends are reinvestment in real assets or investment } \\
\text { in the high-tax affiliate }\end{array}\end{array}$} \\
\hline & $\begin{array}{l}\text { End of } \\
\text { period } 0\end{array}$ & End of period 1 & End of period 2 \\
\hline $\begin{array}{l}\text { From parent to: } \\
\text { low-tax affiliate } \\
\text { high-tax affiliate }\end{array}$ & $\begin{array}{l}\mathrm{K}_{\mathrm{L}, 0} \\
\mathrm{~K}_{\mathrm{H}, 0}\end{array}$ & $\begin{array}{l}\mathrm{K}_{\mathrm{L}, 1}-\mathrm{K}_{\mathrm{L}, 0} \\
\mathrm{~K}_{\mathrm{H}, 1}-\mathrm{K}_{\mathrm{H}, 0}\end{array}$ & \\
\hline $\begin{array}{l}\text { To parent from: } \\
\text { low-tax affiliate } \\
\text { high-tax affiliate }\end{array}$ & & $\begin{array}{l}D_{L}\left(1-t_{L, d}\right) \\
D_{H}\left(1-t_{H, d}\right)+H\end{array}$ & $\begin{array}{l}\mathrm{f}_{\mathrm{L}}\left(\mathrm{K}_{\mathrm{L}, 1}+\mathrm{R}_{\mathrm{L}}\right)(1-\mathrm{t})+\mathrm{K}_{\mathrm{L}, 1}+\mathrm{R}_{\mathrm{L}}\left(1-\mathrm{t}_{\mathrm{L}, \mathrm{d}}\right)+\mathbf{H}\left(\mathbf{1}-\mathrm{t}_{\mathrm{L}, \mathrm{d}}\right) \\
\quad+\mathbf{s f}_{\mathbf{H}}\left(\mathbf{K}_{\mathbf{H}, \mathbf{1}}+\mathbf{R}_{\mathbf{H}}\right)(\mathbf{1 - t}) \\
\mathrm{f}_{\mathrm{H}}\left(\mathrm{K}_{\mathrm{H}, 1}+\mathrm{R}_{\mathrm{H}}\right)(1-\mathrm{t})+\mathrm{K}_{\mathrm{H}, 1}+\mathrm{R}_{\mathrm{H}}\left(1-\mathrm{t}_{\mathrm{H}, \mathrm{d}}\right)-\mathbf{H} \\
\quad-\mathbf{s f}_{\mathbf{H}}\left(\mathbf{K}_{\mathbf{H}, \mathbf{1}}+\mathbf{R}_{\mathbf{H}}\right)(\mathbf{1 - t})\end{array}$ \\
\hline $\begin{array}{l}\text { Interaffiliate } \\
\text { transactions: } \\
\text { from low-tax to high- } \\
\text { tax affiliate } \\
\text { from high-tax to low- } \\
\text { tax affiliate } \\
\end{array}$ & & $\mathbf{H}$ & $\begin{array}{l}H+\mathbf{s f}_{H}\left(K_{H, 1}+R_{H}\right)\left(1-t_{H}\right) \text { plus U.S. foreign tax } \\
\text { credit of } t_{H}{ }^{*} f_{H}\left(K_{H, 1}+R_{H}\right)\end{array}$ \\
\hline
\end{tabular}

Note that the high-tax subsidiary can return equity received from the parent tax-free at the end of period 1 if it pays out all of its earnings in dividends. This means that part (or all) of the original equity transfer at the end of period 0 can be replaced with earnings transferred from the low-tax subsidiary without any U.S. tax consequences. Equity repatriations from the high-tax affiliate to the parent can be used in this way to route earnings from the low-tax affiliate to the parent without incurring any repatriation tax. 
The parent does face some constraints on the size of the inter-affiliate equity transfer: $\mathrm{H}$ can not exceed total equity held in the high-tax subsidiary in the second period (since it must be remitted when the firm is closed) or after-host-country-tax earnings in the low-tax subsidiary at the end of period one (since there is no alternate source of funds). The formal problem faced by the parent is to choose an investment and repatriation strategy $\left(\mathrm{K}_{\mathrm{L}, 0}, \mathrm{~K}_{\mathrm{L}, 1}, \mathrm{~K}_{\mathrm{H}, 0}, \mathrm{~K}_{\mathrm{H}, 1}, \mathrm{R}_{\mathrm{L}}, \mathrm{R}_{\mathrm{H}}, \mathrm{D}_{\mathrm{L}}, \mathrm{D}_{\mathrm{H}}\right.$ and $\left.\mathrm{H}\right)$ to maximize the present value of net cash-flows to the parent subject to the following constraints $\frac{16}{16}$

$$
\begin{gathered}
D_{L}=f_{L}\left(K_{L, 0}\right)\left(1-t_{L}\right)-R_{L}-H, \\
D_{H}=f_{H}\left(K_{H, 0}\right)\left(1-t_{H}\right)-R_{H} \\
H \leq K_{H, 1} \text { and } H \leq f_{L}\left(K_{L, 0}\right)\left(1-t_{L}\right)
\end{gathered}
$$

There are two regions of solutions depending on which of the $\mathrm{H}$ constraints bind. 17 Consider first the case in which the high-tax subsidiary is "large" relative to after-tax earnings in the low-tax subsidiary: $\mathrm{H}<\mathrm{K}_{\mathrm{H}, 1}$ and $\mathrm{H}=\mathrm{f}\left(\mathrm{K}_{\mathrm{L}, 0}\right)\left(1-\mathrm{t}_{\mathrm{L}}\right)$. Under the usual arbitrage condition, this case is identical to the passive assets case considered above. To see this, simply replace $\mathrm{H}$ with $\mathrm{P}$ in chart 3 . The equity transfer from the high-tax subsidiary to the parent at the end of period 1 , now written $\mathrm{P}$, is equivalent to a transfer at the end of period 2 of $\mathrm{P}(1+\mathrm{r})=\mathrm{P}(1+\mathrm{i}(1-\mathrm{t}))$. Since the two cases are completely analogous, the first-order conditions for investment in the high-tax and low-tax affiliate, respectively, are identical to equations (3) and (4). $\frac{18}{1}$ As in the passive asset case, the parent need not underinvest in the low-tax CFC in order to get the benefits of deferral because it can always obtain a "normal" after-tax return $r$ on its earnings by using its high-tax affiliate as a vehicle for making tax-free repatriations.

\footnotetext{
${ }^{16}$ The problem can be simplified by noting from the previous section that equity injections dominate reinvestment of profits in the high-tax country so that $\mathrm{R}_{\mathrm{H}}=0$.

${ }_{17}^{17}$ We ignore the knife-edge case in which both bind.

${ }^{18}$ In a longer horizon in which the high-tax affiliate's final payback of initial equity is in the distant future the firstorder condition is again the Hartman-Sinn rule: $f_{L}^{\prime}=r /\left(1-t_{L}\right)$. Eventually, however, the high-tax affiliate will have repaid all of its initial equity injection, so the infinite time horizon solution is not quite applicable. In that case, the solution is similar to the finite horizon, passive assets, model in the previous section. Still, in a more realistic case where the subsidiaries have growing demands for capital because of economic growth or change in technology, the final payback of the high-tax subsidiary's initial equity may be in the distant future.
} 
It is important to note that the "triangular" strategy is different from the usual "cross-crediting" or "averaging" case. In the latter, the two subsidiaries make simultaneous direct repatriations to the parent and the dividends from the high-tax subsidiary shield the dividends from the low-tax subsidiary from U.S. taxation upon repatriation. While this strategy may leave a residual U.S. tax, there would not be one in the triangular strategy.

One way of clearly distinguishing the consequences of "cross-crediting" from our triangular case is to consider a situation in which the "high-tax" subsidiary is located in a country with a corporate tax rate just equal to the U.S. corporate rate. In this scenario direct dividends from the low-tax subsidiary generate residual U.S. taxes regardless of whether the "high-tax" subsidiary simultaneously makes a dividend payment to the parent. This is because the direct dividend from the "high-tax" subsidiary generates no excess credits to absorb the residual U.S. tax liability on the remittance from the low-tax subsidiary since the tax rate is the same in the high-tax subsidiary as in the U.S. As a result, remittances of earnings from the low-tax subsidiary incur repatriation taxes. The triangular strategy, on the other hand, allows the parent to effectively avoid repatriation taxes on returns from investment in the low-tax subsidiary.

What if the parent is constrained in its use of the triangular strategy by the optimal size of the high-tax subsidiary? In this case the high-tax subsidiary is "small" relative to after-tax earnings in the low-tax subsidiary: $\mathrm{H}=\mathrm{K}_{\mathrm{H}, 1}$ and $\mathrm{H}<\mathrm{f}_{\mathrm{L}}\left(\mathrm{K}_{\mathrm{L}, 0}\right)\left(1-\mathrm{t}_{\mathrm{L}}\right)$. The parent is unable to avoid the repatriation tax on the returns to marginal investment in the low-tax subsidiary since they can not be funneled through the high-tax subsidiary and, as a result, the parent will underinvest $\left(\mathrm{R}_{\mathrm{L}}>0\right)$. We are back in the Hartman-Sinn case--- equity is trapped in the low-tax subsidiary due to the positive repatriation tax. As a result, the first-order conditions for marginal investment in the low-tax subsidiary are given by our original equations (1) and (2).

Since the size of the original equity injection in the high-tax subsidiary does not effect the parent's use of the triangular repatriation strategy the cost of capital in this case is initially the standard one: $\mathrm{f}_{\mathrm{H}}^{\prime}\left(\mathrm{K}_{\mathrm{H}, 0}\right)=\mathrm{r} /(1-\mathrm{t})$. However, in period 2 the cost of capital falls as a result of the repatriation benefit 
of using the triangular strategy: $\mathrm{f}_{\mathrm{H}}^{\prime}\left(\mathrm{K}_{\mathrm{H}, 1}\right)=\mathrm{r} /\left(1-\mathrm{t}_{\mathrm{L}}\right)$. Equity is now trapped in both the high and low-tax affiliate! This leads to underinvestment in both affiliates.

\section{Using Multiple Tiers to Reduce Repatriation Taxes}

Up to this point we have assumed that parents capitalize their affiliates directly. In fact, it is possible that there will be situations in which the parent's optimal strategy is to first inject additional equity to a high-tax subsidiary which then invests the equity in a low-tax sibling. As mentioned above, the advantage of this strategy is that the low-tax affiliate can repatriate earnings to the parent through the high-tax affiliate with a lower "blended" repatriation tax rate. Specifically, the "gross up" tax rate that determines the credit on the dividends passing through the high-tax subsidiary is:

$\frac{\text { taxes paid by high-tax CFC }+ \text { pro-rata share of taxes paid by low-tax CFC }}{\text { high-tax earnings } \& \text { profits }+ \text { pro-rata share of low-tax earnings } \& \text { profits }}$.

We do not include this strategy as an explicit option in the theoretical model because the triangular strategy that we considered would always dominate in a two-period, stationary investment function model where it is available. In that strategy, in which the low-tax subsidiary invests in the hightax subsidiary, the MNC can achieve a fully tax-free repatriation and all potential high-tax credits are used because the high-tax affiliate repatriates all of its income. The "blending" strategy, on the other hand, depends on the high-tax affiliate not repatriating all of its income. If it did, the U.S. tax on the combined repatriations would be the same as if the two entities just repatriated directly to the parent. All available credits would be used.

But in a more general multi-period model in which investment opportunities are growing over time, the "multiple tiers" strategy may be preferable. There is the possibility that the "triangular" strategy analyzed above cannot be maintained indefinitely because eventually the low-tax subsidiary would own 100 percent of its high-tax sibling. Furthermore, in a growing world, the high-tax subsidiary would, given a constant cost of capital, increase its capital stock over time anyway. The low-tax subsidiary can, therefore, lower its repatriation tax by "borrowing" credits from the high-tax subsidiary which doesn't 
need them because it would not choose to repatriate all of its income. 9 This strategy can also continue to be used in the long run because it does not run into the 100 percent ownership constraint.

A very clear case which illustrates the benefits of the blending strategy is one in which the tax rate in the high-tax affiliate's location is just equal to the U.S. rate. Then there are no spillover credits generated by the high-tax affiliate's dividends and it loses nothing by retaining its income to finance its own growth. Routing the low-tax income through the high-tax subsidiary results in a pure net gain. 20 Of course, rather than having to choose one strategy or the other, MNCs may engage in more complex schemes, such as starting with the "triangular" investment strategy and then switching to the "multiple tiers" strategy.

\section{Dropping the standard arbitrage condition}

Now that we have examined the alternative repatriation strategies we consider how they are affected when we drop the standard arbitrage condition imposed in the previous literature. The standard arbitrage condition eliminates many interesting aspects of companies' financial behavior. It also raises several conceptual issues and seems clearly inconsistent with empirical evidence. First, the arbitrage condition assumes that the worldwide company can use 100 percent debt finance at the margin without increasing its financing costs. 2.1 Second, it assumes that only companies can arbitrage after-tax costs while shareholders passively accept any difference in after-personal-tax returns on debt and equity. And finally, it implies that the real interest rate is higher than the after-corporate-tax return on equity, in contrast to the historically large discrepancy in the opposite direction.

\footnotetext{
${ }^{19}$ This "borrowing of credits" strategy may be optimal even in a two-period, stationary investment function model if no tax-free repatriation options are available. Routing a low-tax dividend through the high-tax subsidiary increases the latter's repatriation tax. The high-tax subsidiary, therefore, retains more after the first period. But the accelerated use of the credits by the low-tax subsidiary may be efficient if it has fewer investment opportunities in the second period than the high-tax subsidiary.

${ }^{20}$ Under subpart F of the U.S. tax code, the payment of the dividend from the low-tax subsidiary to its high-tax upper tier owner will result in a current U.S. tax on the dividend unless the blended tax rate is at least equal to 90 percent of the U.S. rate.

${ }^{21}$ There is a large finance literature based on the premise that the risk of bankruptcy makes borrowing costs rise as the company's debt increases as a percent of its total capitalization. There is also a large literature on debt "rationing" because of asymmetric information (see for example, Stiglitz and Weiss 1981).
} 
We therefore assume that initially, when the company starts borrowing, debt is a cheaper source of finance than equity. That is, $\mathrm{i}(1-\mathrm{t})$ is less than $\mathrm{r}$. As the MNC borrows a greater amount of its capital, the marginal cost of debt increases because of rising expected bankruptcy costs. But how will the assets and borrowing in various locations affect expected bankruptcy costs? We assume that lenders look to the MNC's worldwide assets and liabilities because they know that assets owned by unleveraged low-tax affiliates abroad can be claimed by creditors if the parent is in financial distress.2

Finally, rather than explicitly introducing a rising marginal cost of debt function and solving for the optimal worldwide debt equity ratio in each problem, we make the simplifying assumption that the company faces a worldwide constraint, L, on how large its debt can be as a percent of worldwide assets. In other words, expected bankruptcy costs are minimal below $\mathrm{L}$, and above $\mathrm{L}$ the marginal cost of debt is always above the cost of equity. 23

Irrespective of whether borrowing is done at home or in a high-tax country, $\mathrm{t}$ is the relevant tax rate for interest deductions. If the high-tax country rate is above $t$, the increased value of interest deductions is just offset by the smaller foreign tax credits on the high-tax CFC's repatriations. But it is never optimal to borrow in the low-tax country because we assume that $\mathrm{i}\left(1-\mathrm{t}_{\mathrm{L}}\right)>\mathrm{r}$.

At this point it is interesting to consider how the debt constraint arises. The constraint states that lenders are unwilling to go beyond a certain point in financing the company's assets. This is presumably because the company's real assets and operations are risky. But if some part of the worldwide company has a large balance in Eurodollar deposits, its creditors know that these financial assets can easily be liquidated in order to pay off loans elsewhere in the company if that becomes necessary. The Eurodollar deposits can be used explicitly for "back to back" loans or as collateral, or informally to give creditors a different view of the true risk in the company.

\footnotetext{
${ }^{22}$ Note that because borrowing will tend to be concentrated in the parent (or another high-tax affiliate), the issue is somewhat different from the one discussed by Desai (1997) who dealt with the parent's responsibility for a CFC in financial distress. In the case of the parent, there seems to be no question that its creditors can make a claim on its worldwide assets.

${ }^{23}$ The use of a fixed debt asset ratio is familiar from cost of capital studies such as King and Fullerton (1984) and OECD (1991).
} 
One way to express the role of passive liquid assets in potentially increasing the company's borrowing power is to net passive assets from debt for the purposes of the debt to asset constraint. That is, creditors will base their evaluation of a company's risk of default by looking at its net debt in relation to its operating assets. The netting is done on a worldwide basis because passive assets in one part of the multinational can back loans elsewhere.

It might be claimed that lenders would only net the after-repatriation-tax amount of passive assets against domestic debt because the repatriation tax would be due if the passive assets abroad have to be used to pay off the parent's loans. But a parent in financial distress is very unlikely to have positive taxable income. Indeed, it is likely to have very large tax losses that could absorb a large volume of repatriations. Accordingly, we choose to model the case in which the borrower gets a dollar-for-dollar set-off for the gross amount of passive assets held abroad.

Once borrowing subject to a worldwide debt to asset constraint is possible, the availability of alternatives to dividend repatriation can affect the parent's cost of capital both at home and abroad. To see this, we now allow the parent to invest in a domestic project in periods 1 and 2 with profit function $\mathrm{f}_{\mathrm{D}}(\mathrm{K})$ where $\mathrm{K}$ denotes domestic capital with $\mathrm{f}_{\mathrm{D}}{ }^{\prime}>0$ and $\mathrm{f}_{\mathrm{D}}{ }^{\prime \prime}<0$. For continuity of notation, let $\mathrm{K}_{\mathrm{D}, 0}$ be real capital in the domestic project in period 1 and $\mathrm{K}_{\mathrm{D}, 1}$ equal real capital in period 2.

Assuming that the firm follows optimal debt policy (and therefore does not borrow in the low-tax country) we can abstract from the debt allocation problem. For simplicity, we assume that only oneperiod debt, denoted $\mathrm{B}_{\mathrm{t}}$, is issued at the end of each period $\mathrm{t}(\mathrm{t}=0,1)$. We constrain the amount of debt issued to be less than the capital stock held in the high-tax affiliate and the domestic project: $\mathrm{B}_{0} \leq$ $\mathrm{K}_{\mathrm{D}, 0}+\mathrm{K}_{\mathrm{H}, 0}$. This constraint reflects that as borrowing increases, interest deductions grow and eventually deplete taxable income and the presence of rules that restrict the extent to which a CFC can borrow from related parties (sometimes referred to as "earnings stripping" or "thin capitalization" rules). In what follows, we focus on the case in which this constraint is not binding in the first period. Instead we examine the case in which the debt to asset constraint in the first period binds: $\mathrm{B}_{0} /\left(\mathrm{K}_{\mathrm{D}, 0}+\mathrm{K}_{\mathrm{H}, 0}+\mathrm{K}_{\mathrm{L}, 0}\right)=\mathrm{L}$. 
In period 2, the parent may borrow subject to similar borrowing constraints: (i) ( $\mathrm{B}_{1^{-}}$ $\mathrm{P}) /\left(\mathrm{K}_{\mathrm{D}, 1}+\mathrm{K}_{\mathrm{H}, 1}+\mathrm{K}_{\mathrm{L}, 1}+\mathrm{R}_{\mathrm{H}}+\mathrm{R}_{\mathrm{L}}\right) \leq \mathrm{L}$ and (ii) $\mathrm{B}_{1} \leq \mathrm{K}_{\mathrm{H}, 1}+\mathrm{K}_{\mathrm{D}, 1}$. Note, however, that passive assets can now be used as collateral for second period debt. Chart 4 describes the cash-flows between the parent and its affiliates for this model. We do not show inter-affiliate transactions since they are unchanged from chart 3. (Differences between cash-flows in charts 3 and 4 are highlighted.)

\begin{tabular}{|c|c|c|c|}
\hline \multicolumn{4}{|c|}{$\begin{array}{c}\text { Chart } 4 \\
\text { After-tax cash-flows with borrowing and all alternatives to dividend repatriation }\end{array}$} \\
\hline & $\begin{array}{l}\text { End of } \\
\text { period } 0\end{array}$ & End of period 1 & End of period 2 \\
\hline Proceeds from borrowing & $\mathbf{B}_{0}$ & $B_{1}-B_{0}(1+i(1-t))$ & $-B_{1}(1+i(1-t))$ \\
\hline $\begin{array}{l}\text { From parent to: } \\
\text { low-tax affiliate } \\
\text { high-tax affiliate } \\
\text { domestic project }\end{array}$ & $\begin{array}{l}\mathrm{K}_{\mathrm{L}, 0} \\
\mathrm{~K}_{\mathrm{H}, 0} \\
\mathbf{K}_{\mathbf{D , 0}}\end{array}$ & $\begin{array}{l}\mathrm{K}_{\mathrm{L}, 1}-\mathrm{K}_{\mathrm{L}, 0} \\
\mathrm{~K}_{\mathrm{H}, 1}-\mathrm{K}_{\mathrm{H}, 0} \\
\mathbf{K}_{\mathbf{D}, \mathbf{1}}-\mathbf{K}_{\mathbf{D}, \mathbf{0}}\end{array}$ & \\
\hline $\begin{array}{l}\text { To parent from: } \\
\text { low-tax affiliate }\end{array}$ & & $\mathrm{D}\left(1-\mathrm{t}_{\mathrm{L}, \mathrm{d}}\right)$ & $\begin{aligned} f_{L}\left(K_{L, 1}+R_{L}\right)\left(1-t_{L}\right)\left(1-t_{L, d}\right)+K_{L, 1} \\
+\left(R_{L}+H+P_{L}\right)\left(1-t_{L, d}\right)+i P_{L}(\mathbf{1 - t})\end{aligned}$ \\
\hline high-tax affiliate & & $\mathrm{D}\left(1-\mathrm{t}_{\mathrm{H}, \mathrm{d}}\right)+\mathrm{H}$ & $\begin{aligned} f_{H}\left(K_{H, 1}+\right. & \left.R_{H}\right)\left(1-t_{H}\right)\left(1-t_{H, d}\right)+K_{H, 1} \\
& +\left(R_{H}+P_{H}\right)\left(1-t_{H, d}\right)+\mathbf{i} \mathbf{P}_{H}(\mathbf{1 - t})-H\end{aligned}$ \\
\hline domestic project & & $f_{D}\left(K_{D, 0}\right)(1-t)$ & $f_{D}\left(K_{D, 0}\right)(1-t)+K_{D, 1}$ \\
\hline
\end{tabular}

The problem is to choose debt levels and investment levels in real and financial assets at home and abroad, $\left\{\mathrm{B}_{0}, \mathrm{~B}_{1}, \mathrm{~K}_{\mathrm{D}, 0}, \mathrm{~K}_{\mathrm{D}, 1}\right\}$ and $\left\{\mathrm{K}_{\mathrm{j}, 0}, \mathrm{~K}_{\mathrm{j}, 1}, \mathrm{H}, \mathrm{D}_{\mathrm{j}}, \mathrm{R}_{\mathrm{j}}, \mathrm{P}_{\mathrm{j}}\right.$ for $\mathrm{j}=\mathrm{L}$ and $\left.\mathrm{H}\right\}$ to maximize the present value of net cash-flows to the parent subject to the following constraints:

(i)

$$
\begin{aligned}
& D_{L}=f_{L}\left(K_{L, 0}\right)\left(1-t_{L}\right)-R_{L}-P_{L}-H \\
& D_{H}=f_{H}\left(K_{H, 0}\right)\left(1-t_{H}\right)-R_{H}-P_{H}
\end{aligned}
$$

$$
\frac{\mathrm{B}_{0}}{\mathrm{~K}_{\mathrm{D}, 0}+\mathrm{K}_{\mathrm{H}, 0}+\mathrm{K}_{\mathrm{L}, 0}}=\mathrm{L}
$$

$$
\mathrm{B}_{0}<\mathrm{K}_{\mathrm{D}, 0}+\mathrm{K}_{\mathrm{H}, 0}
$$

$$
\frac{\mathrm{B}_{1}-\mathrm{P}}{\mathrm{K}_{\mathrm{D}, 1}+\mathrm{K}_{\mathrm{H}, 1}+\mathrm{K}_{\mathrm{L}, 1}+\mathrm{R}_{\mathrm{H}}+\mathrm{R}_{\mathrm{L}}} \leq \mathrm{L}
$$




$$
\mathrm{B}_{1} \leq \mathrm{K}_{\mathrm{H}, 1}+\mathrm{K}_{\mathrm{D}, 1}
$$

(vi) $\quad \mathrm{H} \leq \mathrm{K}_{\mathrm{H}, 1}$

(vii) $\quad \mathrm{H} \leq \mathrm{f}_{\mathrm{L}}\left(\mathrm{K}_{\mathrm{L}, 0}\right)\left(1-\mathrm{t}_{\mathrm{L}}\right)$

The solution regions depend on which combination of the last four constraints (iv)-(vii) are binding. Since debt is a cheap source of finance, one of the two second period debt constraints will bind [either (iv) or (v)]. In addition, there will be different solutions depending on the H constraints [(vi) and (vii)]. 24 We divide our discussion of the solution regions by the debt constraints. In case 1, constraint (iv) binds and the parent can borrow fully against passive assets. In case 2, constraint (v) binds. In both cases, since there is no advantage to deferral, all earnings in the high-tax subsidiary are repatriated at the end of each period $\left(\mathrm{P}_{\mathrm{H}}=0\right.$ and $\left.\mathrm{R}_{\mathrm{H}}=0\right)$. In addition, since we impose the worldwide debt to asset constraint in period one (constraint ii), the cost of capital in the high-tax affiliate and at home is the usual weighted average of the cost of equity and debt finance: $f_{H}^{\prime}\left(K_{H, 0}\right)=f_{D}^{\prime}\left(K_{D, 0}\right)=r *$ where $r^{*}=r(1-L) /(1-t)+i L$. Investment rules for $\mathrm{K}_{\mathrm{H}, 1}, \mathrm{~K}_{\mathrm{D}, 1}, \mathrm{~K}_{\mathrm{L}, 0}$, and $\mathrm{K}_{\mathrm{L}, 1}$ depend on which borrowing constraints bind in period 2 and the alternatives to repatriation available in each case.

Case 1: $\frac{B_{1}-P_{L}}{K_{D, 1}+K_{H, 1}+K_{L, 1}+R_{L}}=L$ and $B_{1}<K_{H, 1}+K_{D, 1}$ In case 1 , the parent can fund additional investment by borrowing against passive assets held abroad. Investing in passive assets is as good as investing in (or lending to) the high-tax affiliate since passive assets increase the worldwide borrowing constraint (iv) by an equivalent amount. As a result, the parent invests in passive assets and the second $\mathrm{H}$ constraint does not bind: $\mathrm{H}<\mathrm{f}_{\mathrm{L}}\left(\mathrm{K}_{\mathrm{L}, 0}\right)\left(1-\mathrm{t}_{\mathrm{L}}\right)$. The $\mathrm{H}$ constraint has no effect on the optimal investment conditions in this case because the multinational can always fund additional investment with debt. As a result, there is no bonus from expanding investment in the high-tax subsidiary. The first-order conditions for investment are as follows: 


$$
\begin{aligned}
& \mathrm{f}_{\mathrm{H}}^{\prime}\left(\mathrm{K}_{\mathrm{H}, 1}\right)=\mathrm{f}_{\mathrm{D}}^{\prime}\left(\mathrm{K}_{\mathrm{D}, 1}\right)=\mathrm{r} * \\
& \mathrm{f}_{\mathrm{L}}^{\prime}\left(\mathrm{K}_{\mathrm{L}, 0}\right)=\mathrm{f}_{\mathrm{L}}^{\prime}\left(\mathrm{K}_{\mathrm{L}, 1}\right)=\mathrm{r} *\left(\frac{2+\mathrm{r}}{2+\frac{\mathrm{r}}{1-\mathrm{t}_{\mathrm{L}, \mathrm{d}}}}\right) \quad \text { with respect to } \mathrm{K}_{\mathrm{L}, 0} \text { and } \mathrm{K}_{\mathrm{L}, 1}
\end{aligned}
$$

As in the all equity solutions, all operations are capitalized to steady-state levels immediately, and investment in financial assets increases as taxes in the low-tax affiliate decrease. Note that in an infinite horizon setting, the steady-state cost of capital in the low tax affiliate is $f_{L}^{\prime}(\bullet)=r^{*}\left(1-t_{L, d}\right)$. This condition reflects that the parent is borrowing in the U.S. and deferring tax on income in the low-tax country.

Case 2: $\frac{B_{1}-P_{L}}{K_{D, 1}+K_{H, 1}+K_{L, 1}+R_{L}}<L$ and $B_{1}=K_{H, 1}+K_{D, 1}$

In this case, the triangular strategy is attractive since investing within the worldwide multinational keeps the equity in the company, which can support the normal amount of low cost borrowing. The parent will use the triangular strategy until it is up against one of the $\mathrm{H}$ constraints. As in the all equity case, there are two sub-regions of solutions: (a) $\mathrm{H}<\mathrm{K}_{\mathrm{H}, 1}$ and $\mathrm{H}=\mathrm{f}_{\mathrm{L}}\left(\mathrm{K}_{\mathrm{L}, 0}\right)\left(1-\mathrm{t}_{\mathrm{L}}\right.$ ) and (b) $\mathrm{H}=\mathrm{K}_{\mathrm{H}, 1}$ and $\mathrm{H}<$ $\mathrm{f}_{\mathrm{L}}\left(\mathrm{K}_{\mathrm{L}, 0}\right)\left(1-\mathrm{t}_{\mathrm{L}}\right)$. In both cases, since the worldwide debt-to asset constraint does not bind, investment at home is fully funded with debt and the investment rule is $f_{D}^{\prime}\left(K_{D, 1}\right)=i$.

Case 2a: $H<K_{H, 1}$ and $H=f_{L}\left(K_{L, 0}\right)\left(1-t_{L}\right)$

The first-order conditions for investment for this case are:

$$
\begin{aligned}
& \mathrm{f}_{\mathrm{H}}^{\prime}\left(\mathrm{K}_{\mathrm{H}, 1}\right)=\mathrm{i} \\
& \mathrm{f}_{\mathrm{L}}^{\prime}\left(\mathrm{K}_{\mathrm{L}, 0}\right)=\mathrm{f}_{\mathrm{L}}^{\prime}\left(\mathrm{K}_{\mathrm{L}, 1}\right)=\frac{\mathrm{r} *(2+\mathrm{r})+\mathrm{L}\left(\frac{\mathrm{r}}{1-\mathrm{t}}-\mathrm{i}\right)}{2+\frac{\mathrm{r}}{1-\mathrm{t}_{\mathrm{L}, \mathrm{d}}}}
\end{aligned}
$$

\footnotetext{
${ }^{24}$ In our analysis, we ignore the knife-edge corner solutions in which any of the constraints bind simultaneously.
} 
In this case, the low-tax affiliate is "small" relative to the high-tax affiliate and the parent uses only the triangular repatriation strategy. Neither passive assets nor reinvestment is attractive since the high-tax subsidiary has excess equity to repatriate. The cost of capital in period 2 is lower in the high-tax subsidiary than in case 1 since an additional dollar of investment can now be funded by low-cost borrowing (recall that in this case $\mathrm{B}_{1}=\mathrm{K}_{\mathrm{H}, 1}+\mathrm{K}_{\mathrm{D}, 1}$ ). At the same time, the marginal cost of investing in the low-tax affiliate increases, relative to case 1 , by $\mathrm{L}(\mathrm{r} /(1-\mathrm{t})-\mathrm{i})$ since this investment can not support additional low-cost borrowing at home.

Case $2 b: H=K_{H, 1}$ and $H<f\left(K_{L, 0}\right)\left(1-t_{L}\right)$

In this case, the high-tax affiliate is "small" relative to after-tax earnings in the low-tax affiliate. As a result, the parent invests in both the high-tax subsidiary and in passive assets. 5 The investment rules are:

$$
\begin{aligned}
& \mathrm{f}_{\mathrm{H}}^{\prime}\left(\mathrm{K}_{\mathrm{H}, 1}\right)=\mathrm{i}-\left(\frac{\mathrm{r}}{1-\mathrm{t}}-\mathrm{i}\right) \\
& \mathrm{f}_{\mathrm{L}}^{\prime}\left(\mathrm{K}_{\mathrm{L}, 0}\right)=\mathrm{f}_{\mathrm{L}}^{\prime}\left(\mathrm{K}_{\mathrm{L}, 1}\right)=\frac{\mathrm{r} *(2+\mathrm{r})+\mathrm{L}\left(\frac{\mathrm{r}}{1-\mathrm{t}}-\mathrm{i}\right)}{2+\mathrm{i}\left(1-\mathrm{t}_{\mathrm{L}}\right)}
\end{aligned}
$$

Equation (9) shows that the cost of capital in the high-tax subsidiary in period two is even less than the cost of borrowing since any additional equity can support the triangular strategy. The cost of capital in the low-tax affiliate is higher than in case 2 a since the returns to additional investment earn the lower passive asset return and not the return on equity available when after-tax earnings can be transferred home through the high-tax affiliate.

\subsection{Incentives for excess credit parents: The allocation of debt}

\footnotetext{
${ }^{25}$ As in the "passive assets only" model, concavity of $f_{\mathrm{L}}$ implies that reinvestment in real assets is not optimal in this case.
} 
Introducing a worldwide debt to asset constraint may also affect the financing and investment decisions of multinationals in excess credit positions. ${ }^{26}$ To see this we analyze a simple model in which the parent can borrow both at home and on the local market to fund investment projects. 27 As before, we assume that the multinational's worldwide debt to asset ratio may not exceed $\mathrm{L}$ and that the affiliate (parent) can not borrow more than the capital stock abroad (at home). We also continue to assume that $\mathrm{i}\left(1-\mathrm{t}_{\mathrm{L}}\right)>\mathrm{r}$. For simplicity, we ignore the presence of any withholding taxes on dividends.

When the parent is an excess credit position there is no advantage to deferral. Consequently, all alternatives to dividend repatriation are equivalent and are dominated by dividends. The parent optimally repatriates all profits at the end of each year. As a result, the two period problem reduces to single period problem which is repeated in the second year (or indefinitely in an infinite horizon problem). The firm chooses $\mathrm{B}_{\mathrm{D}}, \mathrm{B}_{\mathrm{H}}, \mathrm{B}_{\mathrm{L}}, \mathrm{K}_{\mathrm{D}}, \mathrm{K}_{\mathrm{H}}$ and $\mathrm{K}_{\mathrm{L}}$ to solve the following problem subject to the constraints described above:

$$
\begin{gathered}
\max \left(f_{D}\left(K_{D}\right)-i B_{D}\right)(1-t)+\left(f_{L}\left(K_{L}\right)-i B_{L}\right)\left(1-t_{L}\right)+\left(f_{H}\left(K_{H}\right)-i B_{H}\right)\left(1-t_{H}\right)-r\left(K_{L}+K_{H}+K_{D}-B_{L}-B_{H}-B_{D}\right) \\
\text { subject to } \frac{B_{L}+B_{H}+B_{D}}{K_{L}+K_{H}+K_{D}} \leq L \\
B_{L} \leq K_{L}, B_{H} \leq K_{H}, \text { and } B_{D} \leq K_{D}
\end{gathered}
$$

where $\mathrm{B}_{\mathrm{D}}$ represents debt on the domestic company's books, $\mathrm{B}_{\mathrm{L}}$ represents debt on the low-tax CFC's books, and $\mathrm{B}_{\mathrm{H}}$ represents debt on the high-tax CFC's books. Faced with this problem, the firm will allocate as much debt abroad in the high-tax country as possible $\left(\mathrm{B}_{\mathrm{H}}=\mathrm{K}_{\mathrm{H}}\right)$ and will not borrow in the

\footnotetext{
${ }^{26}$ Altshuler and Mintz (1995) solve a similar debt allocation problem in the presence of the recent U.S. rules requiring that parents allocate a portion of interest expense to foreign income. These allocations reduce allowable foreign tax credits and reinforce the incentive for shifting (unrelated) debt to high-tax foreign affiliates that is the subject of this section. For simplicity, we have not incorporated the interest allocation rules into our model.

${ }^{27}$ Borrowing in different countries may not be perfect substitutes for non-tax reasons, contrary to the assumption in the theoretical model. Exchange rate uncertainty may be one reason, although the location of borrowing does not necessarily determine which currency the debt is denominated in. The subsidiary can presumably borrow in dollars and the parent can borrow in foreign currency. In addition, as Desai (1997) suggests, country rules on creditor rights might affect interest costs (even in the same currency), although parent guarantees might offset this consideration. In any case, we wish to focus on tax considerations and, therefore, abstract from currency risks or creditor rights.
} 


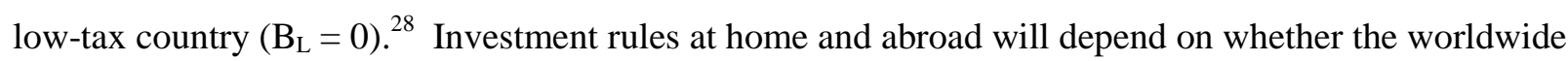
debt to asset constraint is binding or the domestic debt constraint $\left(\mathrm{B}_{\mathrm{D}} \leq \mathrm{K}_{\mathrm{D}}\right)$ binds.

Case 1: $B_{D}<K_{D}$ and $\frac{B_{L}+B_{H}+B_{D}}{K_{L}+K_{H}+K_{D}}=L$

The first-order conditions are:

$$
\begin{aligned}
& f_{H}^{\prime}\left(K_{H}\right)=\frac{r(1-L)}{1-t_{H}}+i L-i(1-L)\left(\frac{t_{H}-t}{1-t_{H}}\right) \\
& f_{D}^{\prime}\left(K_{D}\right)=r * \\
& f_{L}^{\prime}\left(K_{L}\right)=\frac{r(1-t)}{1-t_{L}}+i L-i L\left(\frac{t-t_{L}}{1-t_{L}}\right)
\end{aligned}
$$

Equation (11) shows that the cost of capital in the high-tax subsidiary is lower than the standard one since extra investment in real assets increases the parent's worldwide debt capacity. The affiliate could always borrow $\mathrm{L}$ and deduct interest costs at the tax rate $\mathrm{t}_{\mathrm{H}}$ even without any debt reallocation. But with debt reallocation, the affiliate borrows $1-\mathrm{L}$ in addition, which would ordinarily be financed with equity. Its cost of capital is therefore reduced by 1-L times the increased interest deductions from the reallocation. The cost of capital is lower than the standard one in the low-tax affiliate for similar reasons. Debt reallocation allows the affiliate to borrow $\mathrm{L}$ in addition at a lower cost and save $\mathrm{iL}\left(\mathrm{t}-\mathrm{t}_{\mathrm{L}}\right)$. It is also interesting to note that the cost of capital in the low-tax affiliate is the same as in the (infinite horizon) deficit credits case in which the parent funds additional investment by borrowing against passive assets.

Case 2: $B_{D}=K_{D}$ and $\frac{B_{L}+B_{H}+B_{D}}{K_{L}+K_{H}+K_{D}}<L$

The first-order conditions are:

\footnotetext{
${ }^{28}$ We do not discuss in the text the case in which the real capital held in the high-tax CFC is substantial enough to support investment everywhere in the MNC. In this case, $B_{H}<K_{H}$ and $\left(B_{L}+B_{H}+B_{D}\right) /\left(K_{L}+K_{H}+K_{D}\right)=L$. The firstorder conditions for investment are: $\mathrm{f}_{\mathrm{H}}^{\prime}=\mathrm{r}(1-\mathrm{L}) /\left(1-\mathrm{t}_{\mathrm{H}}\right)+\mathrm{iL}, \mathrm{f}_{\mathrm{L}}^{\prime}=\mathrm{r}(1-\mathrm{L}) /\left(1-\mathrm{t}_{\mathrm{L}}\right)+\mathrm{i}\left(1-\mathrm{t}_{\mathrm{H}}\right) \mathrm{L} /\left(1-\mathrm{t}_{\mathrm{L}}\right)$, and $\mathrm{f}_{\mathrm{D}}^{\prime}=\mathrm{r}(1-\mathrm{L}) /(1-\mathrm{t})$ $+\mathrm{iL}\left(1-\mathrm{t}_{\mathrm{H}}\right) /(1-\mathrm{t})$.
} 


$$
\begin{aligned}
& f_{H}^{\prime}\left(K_{H}\right)=f_{D}^{\prime}\left(K_{D}\right)=i \\
& f_{L}^{\prime}\left(K_{L}\right)=\frac{r}{1-t_{L}}
\end{aligned}
$$

The cost of capital is decreased both at home and abroad relative to the standard weighted average cost of capital, $\mathrm{r}^{*}$, since marginal investment can be fully funded with debt. In contrast, the cost of capital in the low-tax country reflects that the parent must fund marginal investment in this $\mathrm{CFC}$ with equity.

\section{Empirical Results}

Our theoretical analysis suggests the various strategies that companies can use to achieve the equivalent of repatriation, i.e., getting cash to the parent, without incurring the tax costs of repatriation:

(1) The foreign subsidiary can invest in passive assets, which the parent can then borrow against. A closely related strategy would be to pay off local debt so that the parent can borrow more.

(2) The low-tax subsidiary can invest in other related foreign affiliates. If the latter are high-tax, they can repatriate their own earnings, paying little or no repatriation taxes because of available credits, while using the infusion from their low-tax siblings for their own investment requirements. Similarly, the low-tax subsidiary can lend its earnings to a related foreign affiliate.

(3) The MNC can lighten the tax cost of repatriations from a low-tax subsidiary by initially injecting capital to it through a high-tax subsidiary which becomes its direct upper-tier owner. The hightax direct owner should be in an exemption or territorial country so that any incoming dividend from its lower-tier affiliate does not attract any further local tax. When the low-tax subsidiary pays a dividend through the upper tier high-tax owner, the dividends that come back to the United States will carry credits that are a blend of the tax rates paid by the high and low-tax siblings.

(4) The MNC can benefit from deferral without having to underinvest. The use of these strategies makes it unlikely that the CFC would have to underinvest early in its history to obtain the benefits of deferral.

We use CFC by CFC balance sheet and payment data to explore the empirical significance of these possible strategies. We also examine the empirical importance of tax considerations in explaining CFC debt holdings. The analysis in section 2.2 suggests that CFC debt should increase with local statutory tax rates. The debt data can also be used to examine strategies closely related to the repatriation tax avoidance scheme outlined above. For instance, a CFC with high potential repatriation taxes would pay off any local debt before investing in passive assets. 
Before proceeding to explain our balance sheet and payment regressions, we should mention a feature of the real world data that may not have been fully reflected in the theoretical model. (It would have added too many complications.) We assumed that the corporate statutory tax rate, the average effective tax rate, and the marginal effective tax rate were all the same. In fact, effective tax rates are frequently lower than the simple statutory tax rate because of incentives such as investment credits. We will, in some specifications, use both as explanatory variables because of their potentially differing impact on behavior. For example, a CFC may be in a country with a low effective tax rate, because of generous incentives, but a high statutory tax rate. The high statutory tax rate may induce a high amount of local debt. At the same time, if its parent is in deficit credit, the CFC will face a high-tax on dividend repatriations because of the low effective tax rate. It will, therefore, have a tax incentive to engage in some of the strategies outlined above.

\subsection{The Data}

The 1996 corporate tax files compiled by the Statistics of Income (SOI) Division of the Internal Revenue Service form the basis for our study of affiliate balance sheets. This data set is constructed from information from three sets of forms filed by U.S. parent corporations: the basic corporate tax form (Form 1120), the form used to claim a foreign tax credit (Form 1118), and Form 5471 which reports on the activities of each CFC of a U.S. parent.

Most of our analysis is confined to the largest 7,500 CFCs in terms of assets because many of the critical variables are only edited by SOI for these companies. Because of various exclusions, such as parents with part-year returns and other data inconsistencies, we are left with about 6,000 CFCs, approximately 4,000 of which are non-financial.

Several types of tax variables appear in the empirical work. Country statutory tax rates and withholding taxes on dividends and interest were obtained from the Price Waterhouse Guides. 29 As

\footnotetext{
${ }^{29}$ The U.S. treaty rates, if any, for the withholding taxes were used. The statutory tax rate used in the analysis, unless otherwise specified, is the rate on manufacturing income.
} 
explained further below, we also calculate country average effective tax rates using information from the Form 5471. These effective tax rates are used to construct the CFC's repatriation taxes. Finally, in some of our regressions we include country-specific information to help control for country non-tax characteristics which may affect CFC balance sheets. These variables, GDP and GDP per capita, come from World Bank tabulations (World Bank 1999).

\subsection{Balance Sheet Information and the Choice of Variables}

Table 1 gives the average asset and liability shares of the CFCs in the sample. The list of assets in this table provide the categories available in the Treasury data for testing the existence of the alternatives to direct repatriation that are the subject of this paper. Identifying "passive" assets, by which we mean liquid, marketable financial instruments issued by unrelated parties, is the most difficult. For the sake of being conservative, we choose "cash" plus "other current assets." The other potential candidates may have important features distinct from "true" passive assets. For example, "accounts receivable" may well include trade loans to related parties that are used to shift income to more favorable locations.

Identifying the "triangular" investment in related parties strategy is more straightforward. We use "Investment in Affiliates" and "Loans to Affiliates" as distinct, separate components of this strategy because they may be influenced by different tax considerations. The choice between these two alternatives may depend on withholding taxes on interest versus dividends and also on the local statutory tax rate. The latter may be important in the choice because dividends in an equity investment can be deferred indefinitely while interest income presumably continues to accrue.

The "multiple tiers" strategy will be identified from the composition of dividends paid by the CFC. The analysis of the allocation of debt among subsidiaries, which as we have noted is related to the dividend-tax avoidance strategies, will be based on the liability categories at the bottom of Table 1.

Table 1 shows that financial assets are clearly significant, indeed they exceed "real" assets, e.g., plant, equipment and inventories, even in non-financial companies. Passive assets (using our definition of 
"cash" plus "other current assets") make up almost thirteen percent of total assets in non-financial CFCs and about fifteen percent of the total assets of all CFCs. Loans to affiliates and investment in affiliates are also quantitatively important, accounting for almost twenty-two percent of total CFC assets when financial CFCs are included, and more than thirteen percent when financial CFCs are excluded.

Before proceeding with the regression analysis, we review the independent variables used in the analysis. Both tax and non-tax variables are included. The repatriation tax on dividends played a critical role in the theoretical model. But we do not use the company's actual repatriation tax (on the margin) which depends on the foreign tax credit position of the parent. One reason is that the theoretical model has focused primarily on the strategies that deficit credit companies use to avoid the repatriation tax. A CFC with an excess credit parent that faces a high dividend repatriation tax (because of a high local withholding tax) might use other strategies such as investing in the parent, which would be the simplest way to get cash back home. ${ }^{0}$ It is, therefore, necessary to distinguish between these two potential sources of a high repatriation tax.

Another reason for not using the standard actual repatriation tax is that the parent may be uncertain about its excess credit position, even in the current year because of audits. If the current position is very close to the excess credit threshold, it may not be a useful guide to the parent's expectations and its resulting strategies.

We, therefore, start out by introducing two separate dividend repatriation taxes into the regressions, one for the repatriation tax that would apply if the parent were in deficit credit, and the other applying to an excess credit parent. Both taxes can be relevant from the company's point of view because each one may possibly apply. We then, in another set of regressions, introduce information on the parent's actual repatriated income and credits without being restricted only to the simple all-or-nothing excess credit threshold. The indicator is the ratio of total foreign taxes paid to total net foreign source

\footnotetext{
${ }^{30}$ This investment in U.S. property would trigger a deemed dividend distribution under the U.S. rules, but this would be shielded by the parent's excess credits.
} 
income. The greater this rate, the less likely the company is to be in deficit credit now or in the future.

The overall foreign tax rate on foreign income is then interacted with the deficit credit repatriation tax and added as another explanatory variable. The coefficient of this interaction term is expected to be negative in the financial asset equations because, as the variable increases, holding the deficit credit repatriation tax constant, the parent is less likely to be in deficit credit in the long run. As a result, it is less likely to be engaging in the strategies that are the major subject of this paper. (In the debt allocation regressions, which are based on the analysis of debt allocation in the excess credit case, we interact the overall foreign tax rate with the local statutory tax rate, which determines the tax saving from interest deductions for excess credit companies.)

Although the theoretical model assumed for simplicity that statutory and effective tax rates are equal it is the CFC's effective tax rate (ETR) that determines the repatriation tax for firms in deficit credit. In particular, in 1996 when the U.S. corporate rate was 35 percent, the deficit credit tax price on dividends was the tax on the grossed up dividend after the credit, or (.35-ETR)/(1-ETR). Our deficit credit repatriation tax is based on the country average effective tax price, not the company-specific tax price, to indicate the more permanent incentives that would determine capital structures. Using the country effective tax rate attempts to eliminate the transitory variations in a company effective tax rate because of timing effects.

Among the few non-tax explanatory variables included in our regressions are two age dummies based on the foreign subsidiary's date of incorporation. One is for companies incorporated within the last five years and the other is for those that were incorporated between five and fifteen years ago. CFC financial behavior may be expected to change as it matures and accumulates profits.

\subsection{Regression Results}

\footnotetext{
${ }^{31}$ Using 1984 and 1992 data, Grubert (forthcoming) finds that there is significant persistence in this rate.

${ }^{32}$ Furthermore, the country average may even be a superior indicator of the CFC's current tax price because the credit on a dividend is based on the entire post-1986 pool of retained earnings.
} 
Table 2 presents the financial asset regressions that attempt to see if companies follow some of the repatriation tax avoidance strategies suggested by the theoretical model. All CFCs, including those in finance, are included. The main issue in these regressions is the influence of the dividend repatriation tax if the parent company is in deficit credit. The theoretical model has, as in the Hartman-Sinn literature, emphasized the case of the low-tax subsidiary with an deficit credit parent. 33

In the first set of regressions in Table 2, for each of the three financial asset categories, the only tax variables are the two dividend tax prices. Consistent with our theoretical analysis, the coefficients of the deficit credit dividend repatriation tax are positive and highly significant. CFCs appear to invest in these alternatives to repatriation when they face a high potential dividend repatriation tax.

The coefficients of the dividend withholding taxes, the tax price if the parent is in excess credit, are negative and significant in one case, for investment in affiliates. But the strategies described above are directed to the more common deficit credit scenario. The CFC with an excess credit parent has other ways of avoiding a host country withholding tax. It can lend money to the parent, which would trigger an income inclusion by the parent but this would be of no consequence if the parent has excess credits. It could also increase payments for royalties and other services. Finally, it is not surprising that a multinational would avoid accumulating financial assets in a country with high withholding taxes on dividends because it runs the risk of paying taxes that cannot be credited.

Since only 42 percent of CFCs made loans to affiliates and 72 percent invested in affiliates we also ran Tobit regressions. The results were generally quite similar, although as usual the Tobit coefficients were much larger in absolute value. The elasticities are comparable once the probability of being above the threshold is factored into the calculation.

In the second set of regressions in Table 2, the host country statutory tax rate is added as an independent variable. The coefficients of the deficit credit dividend repatriation tax remain positive and highly significant for investment in subsidiaries and loans to affiliates. But the coefficient in the passive

\footnotetext{
${ }^{33}$ From 1992 to 1996, an average of about a third of all repatriated manufacturing income was received by parents in excess credit positions.
} 
assets equation becomes negative, which may not be surprising because of the very high (negative) correlation between the statutory tax rate and the dividend tax rate, which depends on the effective tax rate.

The motivation for adding the statutory tax rate as an explanatory variable is that it could be affecting behavior on other margins and biasing the estimated effect of the potential repatriation tax. For example, a low statutory tax rate can attract shifted income, which is then invested in passive assets. 5 Financial assets would presumably be one way in which the retained earnings can be invested. The income shifted to low-tax countries is unlikely to be completely invested in local real assets.

The sensitivity of the passive asset results to the inclusion of the statutory tax rate may be attributable to several other factors. One is that the asset categories available in the balance sheet data make it difficult to identify passive assets very precisely. Also, the theoretical model assumed that borrowing against passive assets is costless. Borrowing-lending spreads may, in fact, be large enough to make triangular strategies more dominant. Investing in or lending to a related foreign affiliate may be clearly preferable as long as, somewhere in the worldwide multinational, a subsidiary would otherwise be obtaining funds from outside sources or from the U.S. parent. Finally, as we noted at the beginning, there is a disadvantage to passive assets since income included in the parent's tax return is in the passive basket and therefore not in a position to absorb spillover credits from active income.

Note that in the equation for investments in other affiliates, the coefficient for the local statutory tax rate is significant and positive. Choosing an equity investment in another affiliate has the advantage of avoiding the local statutory tax rate on any income because dividends can be deferred indefinitely by the lower-tier affiliate. (Indeed the lower-tier affiliate can avoid the upper-tier country tax altogether by lending money directly to the parent.)

\footnotetext{
${ }^{34}$ The Tobit results are available upon request from the authors.

${ }^{35}$ But note that, in the Hartman-Sinn model, any income is repatriated if it is not invested in the CFCs own real assets. A deficit credit parent would, however, only shift income to a low-tax location if the income can be retained there.
} 
The third set of regressions in Table 2 introduce the indicator of the parent's long run credit position described earlier, the overall foreign tax rate on repatriated income, which is interacted with the deficit credit repatriation tax. The interaction term is expected to have a negative coefficient because a larger foreign tax rate makes it less likely than the deficit credit strategies apply. In fact, that turns out to be the case, and furthermore the interaction term is statistically significant for passive assets and loans to affiliates. At the same time, the magnitude of the basic deficit credit repatriation tax coefficient rises compared to the comparable first set of regressions. This evidence suggests that CFCs in low effective tax countries (and thus with high potential deficit credit repatriation taxes) that are controlled by a parent that is far in deficit credit are more likely to be following the strategies hypothesized in this paper.

The last set of regressions on Table 2 include additional country characteristics as explanatory variables and also examine the possibility that CFCs in tax havens are different from other companies. The tax haven dummy is equal to one if the effective tax rate is less than 10 percent. The log of GDP variable is intended to capture the effect of country size and the log of GDP per capita attempts to identify any impact of being in a poor country compared to a rich one.

The addition of these variables does show that passive assets are concentrated in tax havens where the MNC would be facing a very high repatriation tax if it is in deficit credit. The basic deficit credit repatriation tax variable is no longer significant although its interaction with the overall foreign tax rate is significant at the 10 percent level. (The tax haven variable remains highly significant even when the statutory tax rate is added to the regression.) In contrast, the next row shows that CFCs in tax havens are much less likely to invest in other affiliates and the coefficient of the basic deficit credit repatriation tax rate become larger and more significant. Finally, the added variables seem to have very little effect on loans to affiliates, although the GDP and GDP per capita variables themselves are significant.

Table 3 examines the multiple tier strategy, in which a low-tax affiliate is owned by an upper-tier high-tax affiliate. Then any repatriations of low-tax income, which go through the high-tax subsidiary,

\footnotetext{
${ }^{36} \mathrm{We}$ also added industry dummies such as finance and trade to some of the regressions but these did not seem to have much effect on the basic tax results that are the focus of the paper.
} 
can receive greater foreign tax credits from the blend of the high and low tax rates..$^{\text {T. }}$ The dependent variable is the ratio of dividends paid to another CFC to total dividends paid. We expect that CFCs with higher deficit credit repatriation taxes on direct dividends to the United States will make greater use of dividends paid through another CFC.

As mentioned above, another important requirement of the strategy is that the upper tier high-tax CFC be in a dividend exemption (territorial) country where any incoming dividend would not attract any further tax. This would, however, make any dividend withholding tax charged by the low-tier low-tax country costly because it would not be creditable. High dividend withholding taxes on dividends would, therefore, strongly discourage this strategy. The regressions in Table 3, therefore, have the deficit credit tax price of dividends direct to the United States and the dividend withholding tax rate as independent variables. In addition, besides the CFC age dummies, we include the CFC's subpart F income in relation to total assets. A CFC's subpart F income includes items such as interest and dividends and is currently included in the parent's U.S. taxable income. The parent does not, therefore, have to scheme to avoid a repatriation tax on this income because it has already been paid.

Table 3 confirms the significance of this credit-blending strategy. The coefficient of the deficit credit tax price on direct dividends is positive and significant. The coefficient for the local withholding tax on dividends is negative, as expected, and highly significant. The coefficient of the subpart F variable is negative, as expected, but is only of borderline statistical significance.

One of the important consequences of the financial strategies outlined in this paper is that companies will usually not have to "underinvest" in order to take advantage of deferral. Table 4 examines the relationship between the size of a CFC's real capital (or sales) and the time from its date of incorporation to see if the pattern is influenced by the potential repatriation tax. The Sinn underinvestment result would suggest that young CFCs with high potential repatriation taxes would have smaller sales or capital than comparable CFCs not facing a high repatriation tax (see equation 2). The regressions relate

\footnotetext{
${ }^{37}$ The dividend received by the upper tier CFC will be taxed currently by the United States unless the blended foreign tax rate is greater than 90 percent of the U.S. rate.
} 
the (log of) CFC sales or capital to parent size, host country GDP, CFC age, the local effective rate and the interaction of CFC age and the (deficit credit) repatriation tax. The first three variables, parent size, CFC age and local GDP are all statistically significant (the first two are highly significant). The underinvestment hypothesis would suggest that the coefficient of the age repatriation tax interaction variable should be positive (or negative where the inverse of age specification is used). But in various specifications, the interaction of age and the (deficit credit) repatriation tax was statistically significant only in the second and third rows where it has the wrong sign. It is very difficult to identify any "underinvestment" effect.

Table 5 reports on the relationship between CFC debt and the tax variables. In addition to regressions for total debt, we also present separate regressions for related party debt and arms' length borrowing from third parties. In the first set of regressions in Table 4, the independent variables are simply the age dummies, the statutory tax rate and the withholding tax on interest. The regressions show the expected large impact of a higher local statutory tax rate in increasing local debt. $\frac{38}{3}$ The withholding tax rate on interest turns out to have a significant negative effect on the amount of related party debt, where it would be relevant because it applies to cross-border payments.

The second set of regressions in Table 5 add the dividend repatriation tax variables, accumulated retained earnings and the interaction of the deficit credit repatriation tax with accumulated earnings. The purpose is to see whether CFCs use their retained earnings to pay off local debt if they face a high dividend repatriation tax. We see that the coefficient of the interaction of the retained earnings and the

\footnotetext{
${ }^{38}$ In some of the debt regressions, we added the interaction of the statutory rate with the overall foreign tax rate on repatriated income, the indicator of the parent's excess credit position used in Table 2. Parents in excess credit have an added incentive to put debt in high tax countries because it reduces foreign taxes that are not useful as credits. In addition, shifting debt from the United States reduces the domestic interest expense that has to be allocated to foreign income. (If the parent is in deficit credit, a shift of debt from the United States to a high-tax country will reduce useable foreign tax credits by the amount of the tax saving abroad.) The interaction variable, however, has no statistical significance. When the overall foreign tax rate by itself is added as well, it has a positive coefficient while the interaction term is negative, both significant at the 5 percent level. This pattern may suggest that an excess credit parent has an incentive to lower any foreign tax, even in a low-tax country. Debt shifted from the United States to a low-tax country will also yield the lower interest allocation benefit. On the other hand, the analysis of the deficit credit case indicated that MNCs would only borrow in high-tax countries while they defer repatriations in low-tax countries. Thus, an excess credit company may have more debt in low-tax locations than deficit credit companies who want to obtain the full advantage of deferral.
} 
dividend tax variables is negative in all cases and significant for both total debt and unrelated, arms' length debt. Paying off local debt is another version of the passive asset strategy because a CFC with a high repatriation tax will pay off any debt first before accumulating passive assets; it would save the borrowing-lending spread as well as any current U.S. tax on passive interest received. The results seem to confirm that multinationals follow this strategy and provides stronger evidence for the "passive assets" strategy than the direct evidence on actual passive asset holdings.

One potential problem with our empirical results is that they may reflect systematic differences among parents rather than responses to local tax considerations. Some MNCs may, in general, be more highly leveraged or hold more passive assets than others. To test this possibility, we introduced parent fixed effects into the regressions in Tables 2 and 5. We found that the results were generally unaffected by the addition of fixed effects. 99 Indeed, the size of the statutory tax rate coefficient in the debt regressions in Table 5 increases and remains highly significant. In the case of the financial asset regressions in Table 2, the deficit credit repatriation tax remains statistically significant in all cases where it had been in the comparable non-fixed-effects regression. The coefficient is notably smaller in the passive assets and affiliate loans regressions while remaining highly statistically significant. ${ }^{40}$

\section{Conclusions}

Several investment-repatriation strategies are added to the standard model of a parent and its affiliate in which the affiliate is limited to two alternatives: repatriating direct dividends to the parent or investing in its own real operations. We showed that the availability of alternative repatriation strategies can have an effect on real investment in the low-tax subsidiary and throughout the worldwide corporation. If low-tax subsidiaries can achieve the equivalent of tax-free repatriations, they do not have to

\footnotetext{
${ }^{39}$ The fixed effects regression results are not displayed to conserve on space but are available from the authors upon request.

${ }^{40}$ This reduction may not be surprising because it may reflect the fact that parents that tend to invest in low-tax locations tend to follow the strategies that we suggest. These MNCs are the ones we would expect to be the most aggressive tax planners and are also the ones that are more likely to be in permanent deficit credit positions.
} 
"underinvest" initially to obtain the benefits of deferral. If retained lightly-taxed earnings are "trapped" because of the repatriation tax, they are trapped in all foreign subsidiaries as a group, including high-tax ones, because they are able to use the funds.

Firm level balance sheet and payment data for U.S. multinational corporations and their affiliates show the importance of these alternative strategies. The evidence is generally consistent with the theory, particularly the "triangular" strategies using related affiliates. Controlled foreign corporations that face high repatriation taxes make greater investments in related affiliates and send a greater share of their dividends to other foreign affiliates. In addition, they also pay off more local debt as they accumulate retained earnings which is another version of the "passive assets" strategy considered in our analytical model. 


\section{References}

Altshuler, R., Mintz, J., 1995. U.S. Interest Allocation Rules: Effects and Policy. International Taxation and Public Finance 2 (1), 7-35.

Altshuler, R., Newlon, T.S., 1993. The Effects of U.S. Tax Policy on the Income Repatriation Patterns of U.S. Multinational Corporations. In: Giovannini, A., Hubbard, R.G., Slemrod, J. (Eds), Studies in International Taxation. University of Chicago Press, Chicago, pp. 77-115.

Altshuler, R., Newlon, T.S., Randolph, W.C., 1995. Do Repatriation Taxes Matter? Evidence from the Tax Returns of U.S. Multinationals. In: Feldstein, M., Hines, J.R., Hubbard, R.G. (Eds), The Effects of International Taxation on Multinational Corporations. University of Chicago Press, Chicago, pp. 253-272.

Desai, M., 1997. A Multinational Perspective on Capital Structure Choice and Internal Capital Markets. Mimeograph, Harvard Business School.

Grubert, H., forthcoming. Tax Planning by Companies and Tax Competition by Governments: Is There Evidence of Changes in Behavior? Forthcoming in: Hines, J.R. (Ed), International Taxation and Multinational Activity. University of Chicago Press, Chicago.

Grubert, H., 1998. Taxes and the Division of Foreign Operating Income among Royalties, Interest, Dividends and Retained Earnings. Journal of Public Economics 68 (2), 269-90.

Grubert, H., Mutti, J., 1999. Dividend Exemption versus the Current System for Taxing Foreign Business Income. Mimeograph.

Hartman, D., 1985. Tax Policy and Foreign Direct Investment. Journal of Public Economics 26 (1), 10721.

Hines, J.R., Hubbard, R.G., 1990. Coming Home to America: Dividend Repatriations by U.S. Multinationals. In: Razin, A., Slemrod, J. (Eds), Taxation in the Global Economy. University of Chicago Press, Chicago, pp. 161-200.

Hines, J.R., 1994. Credit and Deferral as International Investment Incentives. Journal of Public Economics 55 (October), 323-347.

King, M., Fullerton, D., 1984. The Taxation of Income from Capital: A Comparative Study of the U.S., U.K., Sweden and West Germany. University of Chicago Press, Chicago.

Leechor, C., Mintz, J., 1993. On the Taxation of Multinational Corporate Investment When the Deferral Method is Used by the Capital Exporting Country. Journal of Public Economics 51, 75-96.

OECD, 1991. Taxing Profits in a Global Economy. Paris: OECD.

Price Waterhouse, 1996. Corporate Taxes: A Worldwide Summary, New York.

Sinn, H.W., 1984. Die Bedeutung des Accelerated Cost Recovery System fur den internationalen Kapitalverkehr. Kyklos 37, 542-576. 
Sinn, H.W., 1993. Taxation and the Birth of Foreign Subsidiaries. In: H. Herberg, H., Long, N.V. (Eds), Trade, Welfare, and Economic Policies: Essays in Honor of Murray C. Kemp. University of Michigan Press, Ann Arbor, pp. 325-352.

Stiglitz, J., Weiss, A., 1981. Credit Rationing in Markets with Imperfect Information." American Economic Review 71, 393-410.

Weichenrieder, A.J., 1996. Anti Tax-avoidance Provisions and the Size of Foreign Direct Investment. International Tax and Public Finance 3, 67-81.

Weichenrieder, A.J., (forthcoming). Transfer Pricing, Double Taxation, and the Cost of Capital. Forthcoming in Scandinavian Journal of Economics.

World Bank, 1999. World Economic Indicators. Washington, D.C. World Bank. 
Table 1

\section{Asset and Liability Shares of CFCs in 1996}

\begin{tabular}{|c|c|c|}
\hline Ratio of items to total CFC assets: & Non-financial CFCs & All CFCs \\
\hline \multicolumn{3}{|l|}{ Assets } \\
\hline Cash & .056 & .059 \\
\hline Accounts Receivable & .249 & .221 \\
\hline Other Current Assets & .070 & .094 \\
\hline Loans to Affiliates & .064 & .086 \\
\hline Investment in Affiliates & .073 & .131 \\
\hline Other Investments & .026 & .052 \\
\hline Net Plant and Equipment & .241 & .176 \\
\hline Land and Depletable Assets & .017 & .013 \\
\hline Inventories & .126 & .091 \\
\hline Other Assets & .078 & .077 \\
\hline \multicolumn{3}{|l|}{ Liabilities } \\
\hline Loans from Stockholders & .099 & .110 \\
\hline \multicolumn{3}{|l|}{ Third party debt } \\
\hline Accounts Payable & .167 & .140 \\
\hline Other Current Liabilities & .166 & .160 \\
\hline Other Liabilities & .122 & .129 \\
\hline
\end{tabular}

Notes: This information is taken from the 5471 forms of the controlled foreign subsidiaries filed by nonfinancial parents. Number of observations $=5,981$. 
Table 2

The Effect of Taxes on Financial Assets Held by CFCs

(Dependent variable $=$ Asset Item/Total CFC Assets)

\begin{tabular}{|c|c|c|c|c|c|c|c|c|c|}
\hline Asset Item/Total CFC Assets & $\begin{array}{l}\text { Age Less } \\
\text { Than } \\
5 \text { Years }\end{array}$ & $\begin{array}{c}\text { Age 5-15 } \\
\text { Years }\end{array}$ & $\begin{array}{l}\text { Dividend } \\
\text { Tax in } \\
\text { Deficit } \\
\text { Credit } \\
\end{array}$ & $\begin{array}{l}\text { Withholding } \\
\text { Tax Rate } \\
\text { On } \\
\text { Dividends } \\
\end{array}$ & $\begin{array}{c}\text { Statutory } \\
\text { Tax } \\
\text { Rate } \\
\end{array}$ & $\begin{array}{c}\text { Deficit } \\
\text { Credit Dividend } \\
\text { Tax*Overall } \\
\text { Foreign Tax Rate } \\
\end{array}$ & $\begin{array}{c}\text { Tax } \\
\text { Haven } \\
\end{array}$ & $\begin{array}{c}\text { Log of } \\
\text { GDP }\end{array}$ & $\begin{array}{l}\text { Log of } \\
\text { GDP } \\
\text { per } \\
\text { capita } \\
\end{array}$ \\
\hline Passive Assets & $\begin{array}{c}.011 \\
(1.38)\end{array}$ & $\begin{array}{l}.020 \\
(2.98)\end{array}$ & $\begin{array}{l}.140 \\
(5.13)\end{array}$ & $\begin{array}{l}-.032 \\
(1.00)\end{array}$ & & & & & \\
\hline Investment in Subsidiaries & $\begin{array}{c}.043 \\
(4.23)\end{array}$ & $\begin{array}{l}.006 \\
(.71)\end{array}$ & $\begin{array}{l}.131 \\
(3.98)\end{array}$ & $\begin{array}{l}-.287 \\
(7.55)\end{array}$ & & & & & \\
\hline Loans to Affiliates & $\begin{array}{c}.023 \\
(2.89)\end{array}$ & $\begin{array}{c}.032 \\
(5.06)\end{array}$ & $\begin{array}{c}.139 \\
(5.40)\end{array}$ & $\begin{array}{l}-.035 \\
(1.17)\end{array}$ & & & & & \\
\hline Passive Assets & $\begin{array}{c}.010 \\
(1.25)\end{array}$ & $\begin{array}{c}.020 \\
(2.95)\end{array}$ & $\begin{array}{c}-.154 \\
(3.48)\end{array}$ & $\begin{array}{l}-.107 \\
(3.30)\end{array}$ & $\begin{array}{l}-.347 \\
(8.40)\end{array}$ & & & & \\
\hline Investment in Subsidiaries & $\begin{array}{c}.043 \\
(4.31)\end{array}$ & $\begin{array}{l}.006 \\
(.74)\end{array}$ & $\begin{array}{l}.333 \\
(6.21)\end{array}$ & $\begin{array}{l}-.234 \\
(5.95)\end{array}$ & $\begin{array}{c}.238 \\
(4.77)\end{array}$ & & & & \\
\hline Loans to Affiliates & $\begin{array}{c}.023 \\
(2.92) \\
\end{array}$ & $\begin{array}{c}.032 \\
(5.07) \\
\end{array}$ & $\begin{array}{c}.199 \\
(4.76) \\
\end{array}$ & $\begin{array}{r}-.019 \\
(.62) \\
\end{array}$ & $\begin{array}{c}.071 \\
(1.83) \\
\end{array}$ & & & & \\
\hline Passive Assets & $\begin{array}{c}.001 \\
(.100)\end{array}$ & $\begin{array}{l}.015 \\
(2.29)\end{array}$ & $\begin{array}{l}.153 \\
(3.33)\end{array}$ & $\begin{array}{l}-.024 \\
(.77)\end{array}$ & & $\begin{array}{l}-.278 \\
(2.37)\end{array}$ & & & \\
\hline Investment in Subsidiaries & $\begin{array}{c}.039 \\
(3.10)\end{array}$ & $\begin{array}{l}-.003 \\
(.350)\end{array}$ & $\begin{array}{l}.164 \\
(2.47)\end{array}$ & $\begin{array}{c}-.271 \\
(5.91)\end{array}$ & & $\begin{array}{l}-.046 \\
(.27)\end{array}$ & & & \\
\hline Loans to Affiliates & $\begin{array}{c}.035 \\
(3.49) \\
\end{array}$ & $\begin{array}{c}.041 \\
(5.29) \\
\end{array}$ & $\begin{array}{c}.288 \\
(5.39) \\
\end{array}$ & $\begin{array}{c}-.066 \\
(1.80) \\
\end{array}$ & & $\begin{array}{c}-.367 \\
(2.70) \\
\end{array}$ & & & \\
\hline Passive Assets & $\begin{array}{l}-.005 \\
(.600)\end{array}$ & $\begin{array}{l}.015 \\
(2.19)\end{array}$ & $\begin{array}{l}.024 \\
(.46)\end{array}$ & $\begin{array}{c}-.039 \\
(1.08)\end{array}$ & & $\begin{array}{l}-.220 \\
(1.88)\end{array}$ & $\begin{array}{c}.072 \\
(5.21)\end{array}$ & $\begin{array}{l}-.005 \\
(1.61)\end{array}$ & $\begin{array}{c}.001 \\
(.420)\end{array}$ \\
\hline Investment in Subsidiaries & $\begin{array}{c}.050 \\
(3.94)\end{array}$ & $\begin{array}{l}.001 \\
(.080)\end{array}$ & $\begin{array}{c}.342 \\
(4.62)\end{array}$ & $\begin{array}{l}-.170 \\
(3.23)\end{array}$ & & $\begin{array}{l}-.084 \\
(.500)\end{array}$ & $\begin{array}{l}-.072 \\
(3.59)\end{array}$ & $\begin{array}{l}.003 \\
(.720)\end{array}$ & $\begin{array}{c}.025 \\
(4.86)\end{array}$ \\
\hline Loans to Affiliates & $\begin{array}{c}.042 \\
(4.19)\end{array}$ & $\begin{array}{c}.043 \\
(5.56)\end{array}$ & $\begin{array}{c}.306 \\
(5.14)\end{array}$ & $\begin{array}{l}.015 \\
(.34)\end{array}$ & & $\begin{array}{l}-.336 \\
(2.47)\end{array}$ & $\begin{array}{l}-.014 \\
(.900)\end{array}$ & $\begin{array}{l}-.009 \\
(2.64)\end{array}$ & $\begin{array}{c}.036 \\
(8.81)\end{array}$ \\
\hline
\end{tabular}


Notes: The sample includes all CFCs of non-financial parents $(\mathrm{N}=5,981)$. The columns report OLS coefficients with $\mathrm{t}$-values in parentheses. The adjusted R-squared for all of the regressions were below .15 and many were much lower. Except for the regression in the bottom row of the table, all means of the dependent variables are reported in table 1 . In the third set of regressions using the overall foreign tax rate on repatriated income interacted with the deficit credit dividend tax rate, there are 3,983 observations. The overall foreign tax rate is the ratio of foreign taxes paid on repatriated income to the MNC's total net foreign source income. The tax haven dummy equals 1 if the effective tax rate is less than 10 percent. 
Table 3

The Effect of Dividend Repatriation Taxes on Dividends Paid to Foreign Affiliates

(Dependent Variable $=$ Dividends Paid to Foreign Affiliates/Total Dividends)

\begin{tabular}{lc}
\hline & All CFCs \\
\hline Deficit Credit Tax on Dividends & .208 \\
& $(2.22)$ \\
Withholding Tax on Dividends & -.727 \\
& $(6.20)$ \\
Subpart F Income/CFC Assets & -.098 \\
& $(1.96)$ \\
Ages less than 5 years & .087 \\
& $(2.24)$ \\
Age 5-15 years & .063 \\
& $(2.53)$ \\
\hline & .429 \\
Mean of Dependent Variable & 1,890 \\
Adjusted R squared & .0285 \\
\hline
\end{tabular}

Note: The columns report OLS coefficients with t-values in parentheses. 
Table 4

Do Repatriation Taxes Cause Underinvestment by Immature CFCs?

(Manufacturing CFCs only)

\begin{tabular}{|c|c|c|c|c|c|c|c|c|c|}
\hline $\begin{array}{l}\text { Dependent } \\
\text { variable }\end{array}$ & $\begin{array}{c}\text { Log of } \\
\text { parent } \\
\text { sales }\end{array}$ & $\begin{array}{c}\text { Log of } \\
\text { GDP }\end{array}$ & $\begin{array}{c}\text { Local } \\
\text { effective } \\
\text { tax rate }\end{array}$ & $\begin{array}{c}\text { Age } 1: \\
0-5 \text { years }\end{array}$ & $\begin{array}{c}\text { Age } 2: \\
\text { 5-15 years }\end{array}$ & $\begin{array}{c}\text { Age }{ }^{*} \\
\text { Repatriation } \\
\text { tax }\end{array}$ & $\begin{array}{c}\text { Age } 2 * \\
\text { Repatriation } \\
\text { tax } \\
\end{array}$ & $\begin{array}{l}\text { Inverse Age: } \\
1 /(\text { Age }+5)\end{array}$ & $\begin{array}{l}\text { InverseAge * } \\
\text { Repatriation } \\
\quad \operatorname{tax}\end{array}$ \\
\hline \multirow[t]{2}{*}{ Log of real capital } & $\begin{array}{l}.159 \\
(8.34)\end{array}$ & $\begin{array}{l}.050 \\
(2.04)\end{array}$ & $\begin{array}{l}.409 \\
(.930)\end{array}$ & $\begin{array}{l}-.338 \\
(2.65)\end{array}$ & $\begin{array}{l}-.293 \\
(3.18)\end{array}$ & $\begin{array}{c}1.01 \\
(1.29)\end{array}$ & $\begin{array}{l}.940 \\
(1.77)\end{array}$ & & \\
\hline & $\begin{array}{c}.158 \\
(8.26)\end{array}$ & $\begin{array}{c}.049 \\
(1.99)\end{array}$ & $\begin{array}{c}.870 \\
(1.56)\end{array}$ & & & & & $\begin{array}{l}-4.08 \\
(3.95)\end{array}$ & $\begin{array}{l}13.57 \\
(2.33)\end{array}$ \\
\hline \multirow[t]{2}{*}{$\begin{array}{l}\text { Log of total CFC } \\
\text { sales }\end{array}$} & $\begin{array}{c}.238 \\
(13.0)\end{array}$ & $\begin{array}{l}.076 \\
(3.22)\end{array}$ & $\begin{array}{c}.411 \\
(9.70)\end{array}$ & $\begin{array}{l}-.430 \\
(3.06)\end{array}$ & $\begin{array}{l}-.328 \\
(3.71)\end{array}$ & $\begin{array}{l}-.862 \\
(1.14)\end{array}$ & $\begin{array}{c}1.22 \\
(2.40)\end{array}$ & & \\
\hline & $\begin{array}{c}.235 \\
(12.9)\end{array}$ & $\begin{array}{c}.074 \\
(3.14)\end{array}$ & $\begin{array}{l}-.119 \\
(.220)\end{array}$ & & . & & & $\begin{array}{l}-5.48 \\
(5.58)\end{array}$ & $\begin{array}{l}-2.01 \\
(.360)\end{array}$ \\
\hline
\end{tabular}

Note: Real assets are fixed depreciable assets (buildings and equipment) plus inventories plus land. The repatriation tax is the deficit credit repatriation tax. The sample includes only manufacturing CFCs of non-financial parents (the number of observations=1,949). The columns report OLS coefficients with t-values in parentheses. All of the regressions had adjusted R-squareds of less than .12. 
Table 5

The Effect of Taxes on CFC Debt

(Dependent variable $=$ Liability Item/Total CFC Assets)

\begin{tabular}{|c|c|c|c|c|c|c|c|c|}
\hline$\frac{\text { Liability Item }}{\text { Total CFC Assets }}$ & $\begin{array}{l}\text { Age Less } \\
\text { Than } \\
5 \text { Years }\end{array}$ & $\begin{array}{c}\text { Age } \\
1-15 \\
\text { Years }\end{array}$ & $\begin{array}{l}\text { Statutory } \\
\text { Tax Rate }\end{array}$ & $\begin{array}{c}\text { Withholding } \\
\text { Tax Rate on } \\
\text { Interest }\end{array}$ & $\begin{array}{c}\text { Accumulated } \\
\text { Earnings }\end{array}$ & $\begin{array}{c}\text { Excess } \\
\text { Limit } \\
\text { Tax on } \\
\text { Dividends } \\
\end{array}$ & $\begin{array}{l}\text { Accumulated } \\
\text { Earnings and } \\
\text { Profits* Deficit } \\
\text { Credit Tax }\end{array}$ & $\begin{array}{c}\text { Withholding } \\
\text { Tax Rate on } \\
\text { Dividends }\end{array}$ \\
\hline All CFC Debt & $\begin{array}{l}-.015 \\
(1.33)\end{array}$ & $\begin{array}{l}-.011 \\
(1.30)\end{array}$ & $\begin{array}{c}.393 \\
(11.77)\end{array}$ & $\begin{array}{l}-.036 \\
(.68)\end{array}$ & & & & \\
\hline $\begin{array}{l}\text { Loans from } \\
\text { Stockholders }\end{array}$ & $\begin{array}{c}.046 \\
(5.71)\end{array}$ & $\begin{array}{c}.029 \\
(4.46)\end{array}$ & $\begin{array}{c}.065 \\
(2.65)\end{array}$ & $\begin{array}{l}-.119 \\
(3.00)\end{array}$ & & & & \\
\hline Third Party Debt & $\begin{array}{l}-.061 \\
(5.44)\end{array}$ & $\begin{array}{l}-.018 \\
(1.95)\end{array}$ & $\begin{array}{c}.328 \\
(9.64)\end{array}$ & $\begin{array}{c}.082 \\
(1.51)\end{array}$ & & & & \\
\hline All CFC Debt & $\begin{array}{r}-.064 \\
(5.84)\end{array}$ & $\begin{array}{l}-.014 \\
(1.65)\end{array}$ & $\begin{array}{l}.126 \\
(2.36)\end{array}$ & $\begin{array}{c}.068 \\
(1.08)\end{array}$ & $\begin{array}{l}-.245 \\
(9.03)\end{array}$ & $\begin{array}{l}-.182 \\
(3.00)\end{array}$ & $\begin{array}{l}-.431 \\
(3.01)\end{array}$ & $\begin{array}{l}-.077 \\
(1.52)\end{array}$ \\
\hline $\begin{array}{l}\text { Loans from } \\
\text { Stockholders }\end{array}$ & $\begin{array}{c}.024 \\
(2.91)\end{array}$ & $\begin{array}{l}.018 \\
(2.78)\end{array}$ & $\begin{array}{c}.141 \\
(3.51)\end{array}$ & $\begin{array}{l}-.108 \\
(2.27)\end{array}$ & $\begin{array}{l}-.124 \\
(6.08)\end{array}$ & $\begin{array}{l}.155 \\
(3.40)\end{array}$ & $\begin{array}{l}-.055 \\
(.51)\end{array}$ & $\begin{array}{c}.056 \\
(1.48)\end{array}$ \\
\hline Third Party Debt & $\begin{array}{l}-.088 \\
(7.74)\end{array}$ & $\begin{array}{l}-.032 \\
(3.60)\end{array}$ & $\begin{array}{l}-.015 \\
(.27)\end{array}$ & $\begin{array}{l}.176 \\
(2.69)\end{array}$ & $\begin{array}{l}-.121 \\
(4.29)\end{array}$ & $\begin{array}{l}-.337 \\
(5.36)\end{array}$ & $\begin{array}{l}-.377 \\
(2.53)\end{array}$ & $\begin{array}{l}-.133 \\
(2.53)\end{array}$ \\
\hline
\end{tabular}

Note: The sample includes all CFCs of non-financial parents $(\mathrm{N}=5,981)$. The columns report OLS coefficients with $\mathrm{t}$-values in parentheses. All of the regressions had adjusted R-squareds of less than .10. 